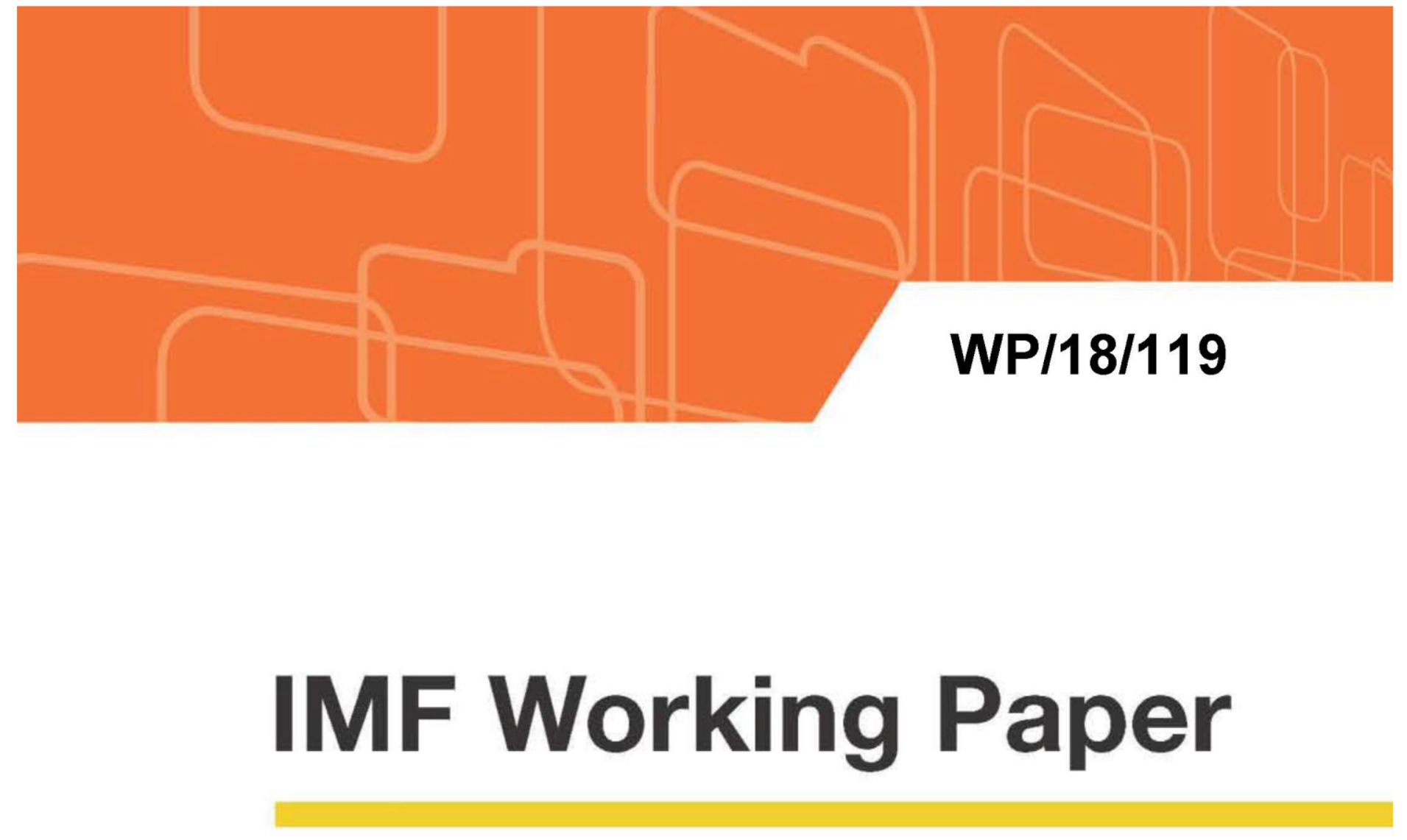

\title{
Australia's Linkages with China: Prospects and Ramifications of China's Economic Transition
}

by Philippe Karam and Dirk Muir

IMF Working Papers describe research in progress by the author(s) and are published to elicit comments and to encourage debate. The views expressed in IMF Working Papers are those of the author(s) and do not necessarily represent the views of the IMF, its Executive Board, or IMF management. 


\section{WP/18/119}

\section{IMF Working Paper}

\section{Australia's Linkages with China: Prospects and Ramifications of China's Economic Transition}

by Philippe Karam and Dirk Muir

IMF Working Papers describe research in progress by the author(s) and are published to elicit comments and to encourage debate. The views expressed in IMF Working Papers are those of the author(s) and do not necessarily represent the views of the IMF, its Executive Board, or IMF management. 


\title{
IMF Working Paper
}

Asia and Pacific Department

\section{Australia's Linkages with China: Prospects and Ramifications of China's Economic Transition}

\author{
Prepared by Philippe Karam and Dirk Muir ${ }^{1}$ \\ Authorized for distribution by Thomas Helbling
}

May 2018

IMF Working Papers describe research in progress by the author(s) and are published to elicit comments and to encourage debate. The views expressed in IMF Working Papers are those of the author(s) and do not necessarily represent the views of the IMF, its Executive Board, or IMF management.

\begin{abstract}
China and Australia have increasingly strong links, especially through trade. These are driven by demand from China for Australian commodities (coal and iron ore) and services (tourism and education). These links are influenced by China's transition to a services-driven, consumer-led economy. Using ANZIMF, the Australia-New Zealand Integrated Monetary and Fiscal model, three risks (both upside and downside) to China during this transition process are considered, focusing on its spillovers to Australia. One simple takeaway is central to each risk - while the real GDP response to shocks in Australia typically is small, responses in demand components or sectors are usually much larger - along with three further takeaways, all of which help in the analysis of Australia in relation to risks emanating from China.
\end{abstract}

JEL Classification Numbers: E12; E17; F41; F43; F47

Keywords: Dynamic stochastic general equilibrium; open economy macoeconomics; small open economy; open economy simulation.

Authors’ E-Mail Addresses: pkaram@imf.org; dmuir@imf.org

\footnotetext{
${ }^{1}$ The authors would like to thank James Daniel and Rui Mano of the IMF's China team, Thomas Helbling, staff at the Australian Treasury and the Reserve Bank of Australia, and participants at an Australian Treasury seminar in Canberra, Australia in November, 2017, for useful comments on an earlier draft.
} 
Table of Contents

I. INTRODUCTION $\underline{4}$

II. STYLIZED FACTS ON LINKAGES BETWEEN AUSTRALIA AND CHINA__ $\underline{\underline{5}}$ III. UPSIDE SCENARIO 1 - HIGHER CHINESE HOUSEHOLD SPENDING ON TOURISM AND EDUCATION $\underline{12}$

IV. UPSIDE SCENARIO 2 - IMPROVED OPPORTUNITIES FOR FOREIGN COMMODITIES SUPPLIERS IN CHINA $\underline{15}$

V. DOWNSIDE SCENARIO - A DISORDERLY REBALANCING IN CHINA __ 17

VI. CONCLUSIONS __ $\underline{23}$

BOX

1. ANZIMF - The Australia-New Zealand Integrated Monetary and Fiscal Model $\underline{8}$

\section{FIGURES}

1. Upside Scenario 1 - Results for China 13

2. Upside Scenario 1 - Spillovers to Australia $\underline{14}$

3. Upside Scenario 2 - Results for China $\underline{16}$

4. Upside Scenario 2 - Spillovers to Australia $\underline{18}$

5. Downside Scenario - Results for China 19

6. Downside Scenario - Spillovers to Australia 21

7. Downside Scenario - Interaction of the Commodities and Services Sectors 22

References $\underline{24}$

\section{ANNEX}

I. Key Assumptions Underlying the Simulations $\underline{25}$ 


\section{INTRODUCTION}

China and Australia have increasingly strong economic and financial linkages, especially through trade and commodity channels. The trade links are driven by demand from China for commodities and services. Key commodities are coal and iron ore used in its intermediate goods industries, like steel. Services imports have a strong consumer component, primarily tourism and education services, for which Australia is also a major supplier. Australian capacity for iron ore and coal production has expanded in the wake of the now-concluded mining investment boom, while services continue to expand in Australia, buoyed by a strong tertiary education system, and growing opportunities for tourism. There are also some financial linkages, but they will not be a focus of the following analysis.

This paper examines the risks to China during its transition and focuses on its spillovers to Australia. While it is acknowledged that China's ongoing transition to a services-driven, consumer-led economy from a manufacturing-driven, export-led one has been largely successful to date, there are still possibilities for upside and downside risks. This paper considers three illustrative risk scenarios, closely focusing on the sectors of China's economy with salient linkages to Australia. ${ }^{2}$ The first two are upside risks for Australia, and the third a downside risk.

- Increased services demand in China. Households substitute away more from saving to consumption while the government enacts reforms to facilitate the process and boost productivity. Australia's service sector benefits, but other sectors face competitive pressures from a more productive China.

- Increased foreign commodities demand from China. China restricts its production of iron ore, coal and associated goods such as steel, although there is still strong Chinese demand for these goods. Australia exports more commodities, but China's resulting mild slowdown in growth triggers a mild contraction elsewhere in the Australian economy driven mainly by an Australian dollar appreciation.

- Disorderly rebalancing in China. The rebalancing process is derailed, leading to a broadbased slowdown in growth with lower productivity, weaker-than-expected performance of the steel industry, lower housing prices, and increased corporate risk. Although Australia's net commodity exports fall, there is a rebalancing between domestic and external demand, and between China and Australia's other trading partners, that stimulates Australia's exports and services sector, on net.

There are four takeaways from these scenarios. The most generally applicable takeaway from all three scenarios is that while real GDP in Australia experiences only small changes, these mask much broader movements in the composition of GDP, whether it be between domestic and

\footnotetext{
${ }^{2}$ For similar scenario analysis that is centered more on China rather than its spillovers using one of the IMF's global models, see Dizioli and others (2016).
} 
external demand, or between sectors in the economy (commodities, services, other tradables, nontradables). The first upside scenario related to China's services demand demonstrates that understanding the components of the shock that occurs in China is as important as its outcomes on the Chinese economy when interpreting the spillovers to Australia. The second upside scenario that focuses on the commodities sector illustrates that Australia is a diversified economy that takes advantage of its flexible exchange rate regime, and its open economy more generally. This takeaway carries over to the downside scenario, which draws out a subtler point - although Australia is a diversified economy, it depends on the interaction of its commodities sector with its multiple trading partners, beyond China alone, and these can have unexpected feedback effects into other sectors of Australia's economy.

The paper explores these scenarios, first by setting up the relevant stylized facts, and then using the Australia-New Zealand Integrated Monetary and Fiscal model (ANZIMF) as its analytical tool. Section B outlines key stylized facts about China and its ongoing transition, the current state of Australia, and both countries' commodity and consumer services sectors, along with their interlinkages. Sections C, D and E present the three scenarios, reflecting shocks to China's transition path as currently articulated by the IMF's 2017 Article IV consultation with China (IMF 2017a) and the World Economic Outlook (IMF 2017b). The analysis in these sections uses ANZIMF, a version of the IMF's Global Integrated Monetary and Fiscal model (GIMF), presented in some detail in Box 1. Section F concludes the paper.

\section{Stylized Facts on Linkages Between Australia And China ${ }^{3}$}

Australia and China have strong economic and financial linkages, resulting from both differences and similarities economic structures. One key similarity is that both are dynamic, growing economies, although Australia is a high-income, advanced economy, while China still is a middle-income economy in transition. Moreover, Australia is shaped by its commodity sector and related exports (albeit with a diversified economy), while China has become the prime global commodity importer (also a diversified economy, but still less dependent on services, and more on industry). Both countries have vibrant service sectors, but China's services sector is still expanding rapidly, particularly in segments dominated by households tourism and education. Australia is in a strong position as a supplier of these services.

\footnotetext{
${ }^{3}$ Sources for data in this section include: ABS; CEIC; China National Bureau of Statistics; Haver Analytics; OECD.stat; and publications by Department of Foreign Affairs and Trade $(2015,2017)$; East Asian Bureau of Economic Research and China Center for International Economic Exchanges (2016); International Energy Administration (2017); International Trade Administration (2017); and Tourism Research Australia (2017).
} 


\section{Box 1. ANZIMF - The Australia-New Zealand Integrated Monetary and Fiscal Model}

ANZIMF is an annual, multi-region, micro-founded general equilibrium model of the global economy. It comprises seven regions - Australia, New Zealand, China, Advanced Asia, Emerging Asia, the United States, and a bloc of the remaining countries; it is an annual, micro-founded DSGE model that includes commodity and services sectors focused on coal/iron ore/metals, and tourism/education services, respectively. ${ }^{1}$ It is based on the IMF's Global Integrated Monetary and Fiscal model (GIMF), with supporting documentation that is applicable to ANZIMF (Kumhof and others, 2010 and Anderson and others, 2013). Structurally, each country/regional block is close to identical, but with different key steady-state ratios and behavioral parameters, based on a stylized data set consistent with 2015 and 2016, and some long-term trends, primarily related to asset holdings (Table 1).

Consumption dynamics are driven by saving households and liquidity-constrained (LIQ) households. Saving households face a consumption-leisure choice, based on the overlapping generations (OLG) model of Blanchard (1985), Weil (1989) and Yaari (1962) where households treat government bonds as wealth since there is a chance that the associated tax liabilities will fall due beyond their expected lifetimes, making the model non-Ricardian and endogenizing the long-term determination of the real global interest rate to equilibrate global savings and investment. The real exchange rate serves to adjust each country's saving position (its current account and associated stock of net foreign assets) relative to the global pool. LIQ households cannot save, consuming all their income each period, amplifying the model's non-Ricardian properties in the short term.

Private investment relies on the BernankeGertler-Gilchrist (1999) financial accelerator. Investment cumulates to the private capital stock for tradable and nontradable firms, which is chosen by firms to maximize their profits, with a standard inverse relationship between the capital-output ratio and the cost of capital. Firms are costly for investors to monitor, and are perceived as riskier as financial conditions (or the economy, more generally) worsen, leading to endogenously determined corporate risk premia.

\begin{tabular}{|c|c|c|c|}
\hline \multicolumn{4}{|c|}{$\begin{array}{l}\text { Table 1. Key Ratios in ANZIMF } \\
\text { (Percent of GDP, unless otherwise stated) }\end{array}$} \\
\hline & Australia & China & Other Asia 1/ \\
\hline Share of Global GDP (\%) & 2.1 & 10.3 & 16.0 \\
\hline \multicolumn{4}{|c|}{ Domestic Demand (\% of GDP) } \\
\hline Household Consumption & 57.2 & 53.5 & 59.0 \\
\hline Private Investment & 20.0 & 25.0 & 20.1 \\
\hline Government Absorption & 22.8 & 24.0 & 21.0 \\
\hline \multicolumn{4}{|l|}{ Trade (\% of GDP) } \\
\hline Non-Commodity Exports & 13.2 & 25.7 & 29.6 \\
\hline Partner 2/ & 1.7 & 0.9 & 0.8 \\
\hline Final Goods & 5.0 & 18.4 & 16.3 \\
\hline Partner 2/ & 0.8 & 0.8 & 0.5 \\
\hline Consumption Services & 3.5 & 2.0 & 2.6 \\
\hline Partner 2/ & 0.9 & $>0$ & 0.2 \\
\hline Intermediate Goods & 4.8 & 5.2 & 10.8 \\
\hline Partner 2/ & 0.9 & 0.1 & 0.3 \\
\hline Non-Commodity Imports & 22.2 & 23.3 & 28.6 \\
\hline Partner 2/ & 4.4 & 0.3 & 0.6 \\
\hline Final Goods & 13.9 & 9.2 & 12.7 \\
\hline Partner 2/ & 3.9 & 0.2 & 0.4 \\
\hline Consumption Services & 2.6 & 2.6 & 1.9 \\
\hline Partner 2/ & 0.1 & 0.2 & 0.2 \\
\hline Intermediate Goods & 5.7 & 11.5 & 14.0 \\
\hline Partner 2/ & 0.6 & 0.2 & 0.1 \\
\hline Net Commodities & 9.0 & -2.4 & -1.0 \\
\hline Partner 2/ & 5.3 & -1.1 & -0.5 \\
\hline \multicolumn{4}{|c|}{$\begin{array}{l}\text { 1/ Includes HKG, IND, IDN, JPN, KOR, MYS, SGP, THA, PHL, VNM and other } \\
\text { small Asian and Pacific island states. } \\
\text { 2/ China in case of Australia; Australia in the case of China and Other Asia. }\end{array}$} \\
\hline
\end{tabular}

${ }^{1}$ Advanced Asia includes Hong Kong SAR of China, Japan, the Republic of Korea, Singapore and Taiwan Province of China. Emerging Asia includes Bangladesh, Cambodia, India, Indonesia, Lao PDR, Malaysia, Mongolia, the Philippines, Sri Lanka, Thailand, Vietnam and other smaller Asian and Pacific island states. The remaining countries bloc includes the rest of the world, but will be dominated by the European Union and the G-20 countries not mentioned in other regions of the model. 


\section{Box 1. ANZIMF - The Australia-New Zealand Integrated Monetary and Fiscal Model (concluded)}

Government absorption consists of exogenously determined spending on consumption goods and infrastructure investment. Both affect the level of aggregate demand. In addition, spending on infrastructure cumulates into an infrastructure capital stock (subject to constant but low rate of depreciation). A permanent increase in the infrastructure capital stock permanently raises the economy-wide level of productivity.

The nominal side of the economy depends on implicit Phillips' curves and monetary policy. The core price is the consumer price index, CPI, while relative prices mimic the structure of the national expenditure accounts. There is also wage inflation, which is implicitly a key driver for CPI inflation. In the short term, the nominal side of the economy is linked to the real side through monetary policy, which is usually an inflation forecast targeting regime that uses an interest rate reaction function reliant on expected inflation. As interest rate effects work their way through the transmission mechanism, inflation moves back to its target level within several years.

Fiscal policy is driven by a sufficiently detailed government sector that can reproduce simplified fiscal accounts for each country. Fiscal policy aims to maintain a debt target (expressed as a deficit target, in flow space) using at least one of seven policy instruments. On the spending side, these are government consumption, spending on infrastructure spending, general lumpsum transfers to all households (such as pensions, aged care provisions, unemployment insurance) and lumpsum transfers targeted to LIQ households (such as welfare, certain pensions). On the revenue side, there are taxes on consumption (the goods and services tax, GST), personal income (PIT) and corporate income (CIT).

Trade is tracked bilaterally between all regions. The flows react to demand, supply and pricing (i.e. the terms of trade and bilateral real exchange rates) conditions. There are flows for non-commodity goods and services, and commodities. Commodities trade, and its related demand and supply equations, are based on coal and metals (especially iron ore). Non-commodities trade is further broken into final goods (consumption and investment), consumption services, and intermediate goods.

Relative to standard versions of GIMF, this model contains sectors for commodities and for services. The data definition for commodities in this application are relatively narrow, covering only coal, iron ore, and other minerals. Similarly, the definition of services is restricted to tourism (mostly travel, accommodation, and food services) and education (mostly travel and correspondence courses).

The commodities sector. The U.S. dollar global commodities price is determined when producing countries sell in a global market, from which all countries then compete for their demands based on price. Countries produce commodities from their endowment. Supply moves in tandem in the short term with the gap between the current and medium-term average global price, and reacts (optionally) to demand-driven long-term changes in the global price. Both the short- and long-term price elasticities of supply are 0.05 . Net export flows are explicitly tracked, although it is possible from the model structure of the model to deduce the bilateral flows. Commodities are inputs to both tradable and non-tradable intermediate goods production, although the majority flows to tradables.

The services sector. Services are produced from tradable and nontradable goods. They are priced as an input for consumption in Australia, or exported to be consumed by foreigners. Services are exclusively part of consumption, and their demand vis-à-vis consumption goods is relatively inelastic. Consumption of services is a combination of services provided domestically or abroad. This allows for a final price of services that will enter the CPI, much as consumption services combines with the consumption of goods to define final household consumption. 
Real GDP growth has been strong since the late 1990s in both countries. China has led the world, while Australia is usually a leader among the advanced economies. Both economies have benefited from strong contributions to growth from aggregate exports.

China has been transitioning towards a servicesdriven economy since the Global Financial Crisis. The share of services in the economy has now reached almost 52 percent of GDP, although it is still lagging that of most advanced economies, while that of industry has declined by around 8 percentage points to 40 percent since 2006 .

Employment restructuring is another factor of the ongoing transition where employment in the primary sector (includes agriculture and mining) having declined since 2002 from 50 percent to about 28 percent, while services increased from 29 percent to 44 percent. Industrial employment has peaked to reach over 30 percent in 2012 , but has slowly declined since.

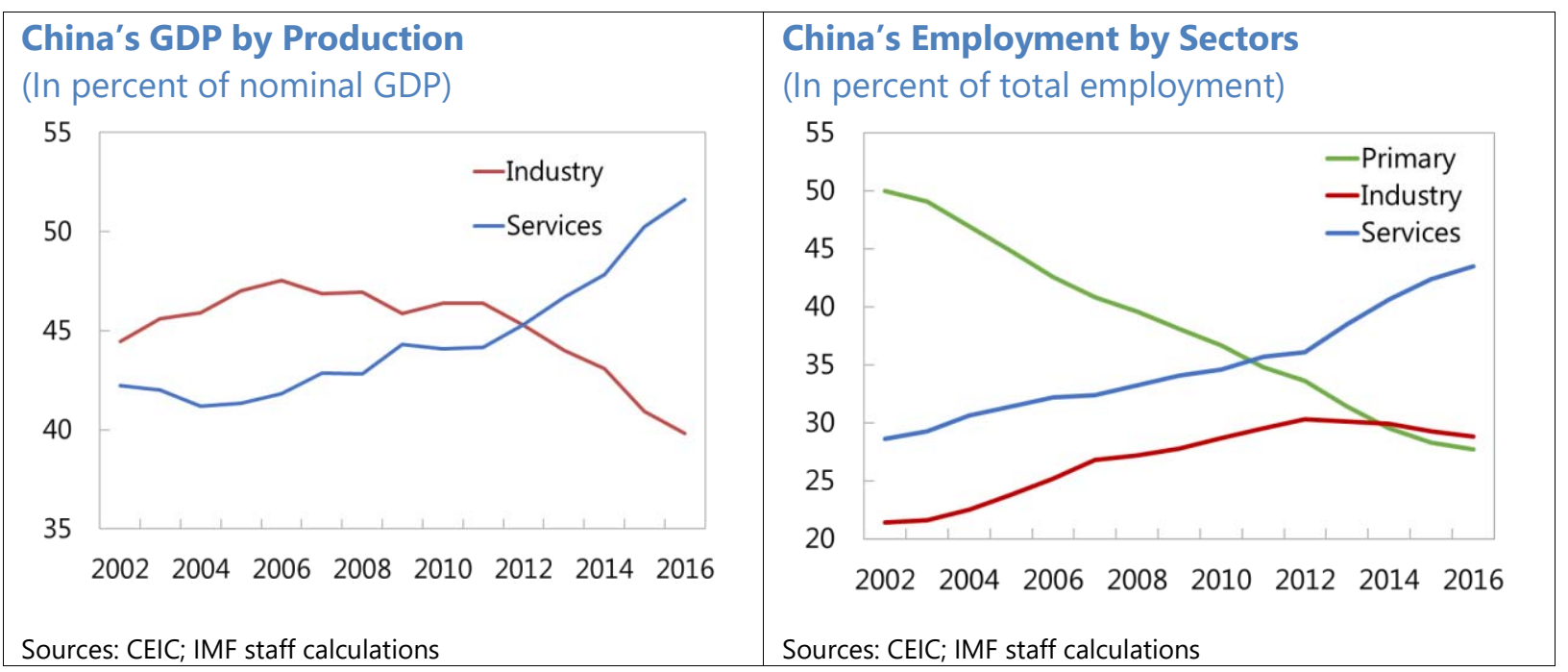

The shift to services has also been reflected in increasing trade in services. China has seen its imports of services rise steadily as a share of GDP, under rapidly growing real GDP. This has been a major driver for Australia's strengthening growth in services exports. In Australia, services exports have been dominated by tourism and education, with China demanding an increasing portion of those exports. 


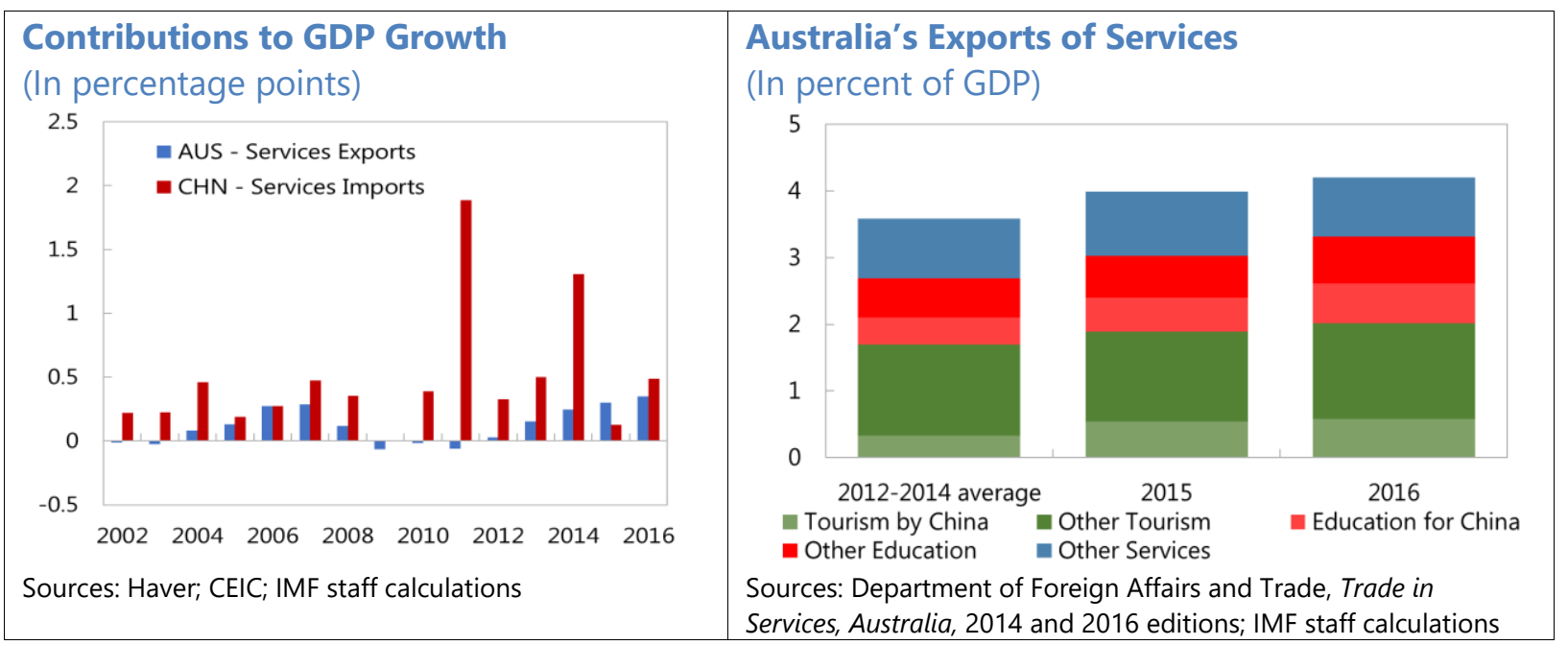

Tourism to Australia from China has been increasing over time, both in value per tourist, and number of tourists. Generally, education and tourism services make up between 11 and 17 percent of GDP in OECD countries. A large portion of tourism spending comes from abroad, and counts as services exports. Tourism is not necessarily the largest component of services exports in many countries - it is often financial services, which is not the case in the ChinaAustralia relationship. China has increased its share of total tourism spending in Australia from 3.5 percent in 2000 to 22 percent in 2015. The strong pace continued in 2015, with strong growth in real per capita spending per tourist from China (29.8 percent), and tourist visits (18.8 percent). The level of spending per Chinese tourist in Australia is above average, at A \$2,523 per tourist. Moreover, where the level of average spending has stayed within A $\$ 150$ of its current value of $A \$ 2,140$ since 2006/07 for other tourists from other countries, spending per tourist from China has increased by 57 percent from $\mathrm{A} \$ 1,610 .^{4}$

\footnotetext{
${ }^{4}$ For tourism and education data, the year 2006/07, for example, indicates the 12 -month period ending June 30 , 2007.
} 


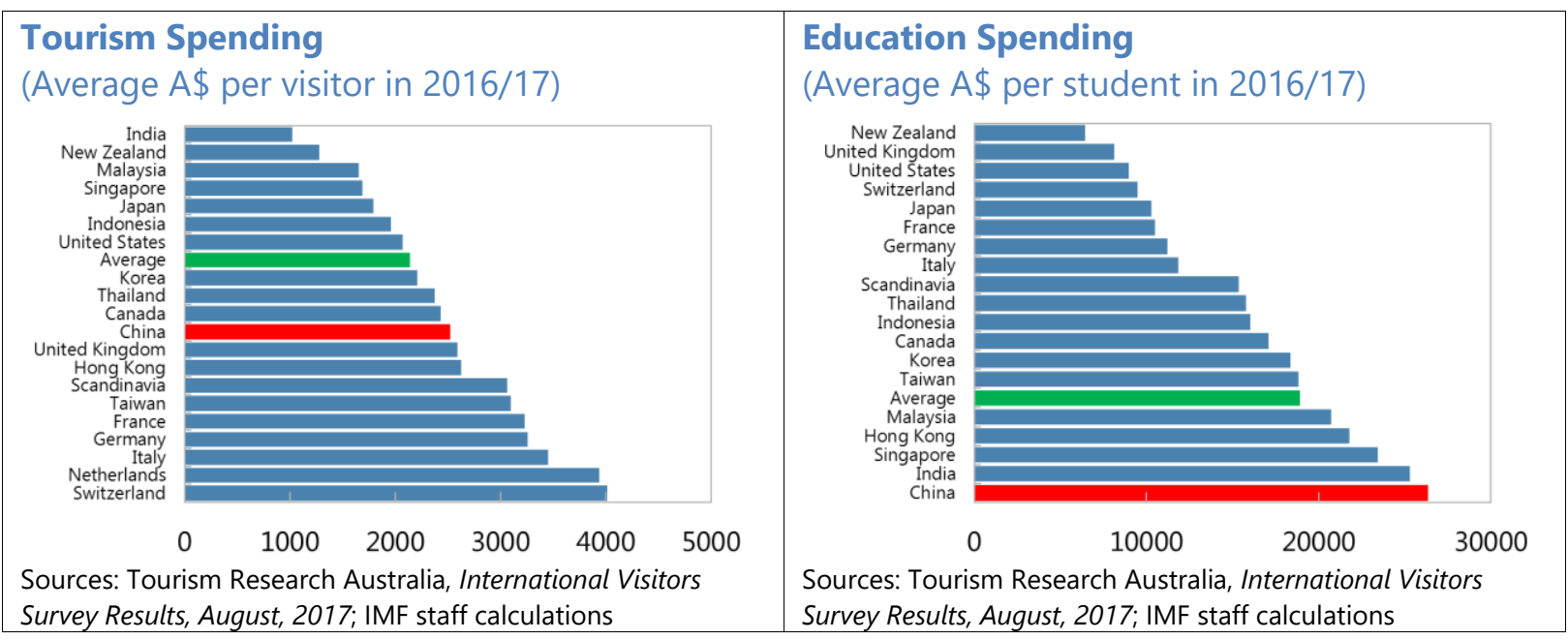

The linkages between China and Australia in education spending tells a similar story. Average education spending from 2006/07 to 2016/17 rose from A\$16,225 to A $\$ 26,350$ by Chinese students (just behind India in percentage increase), although average spending across all countries in Australia has also increased, unlike for tourism, by about 58 percent (versus China's 62 percent). The number of students from China has risen by 340 percent since 2006/07, accounting for over 53 percent of the increase in foreign students, now totaling over 182,000 for 2016/17.

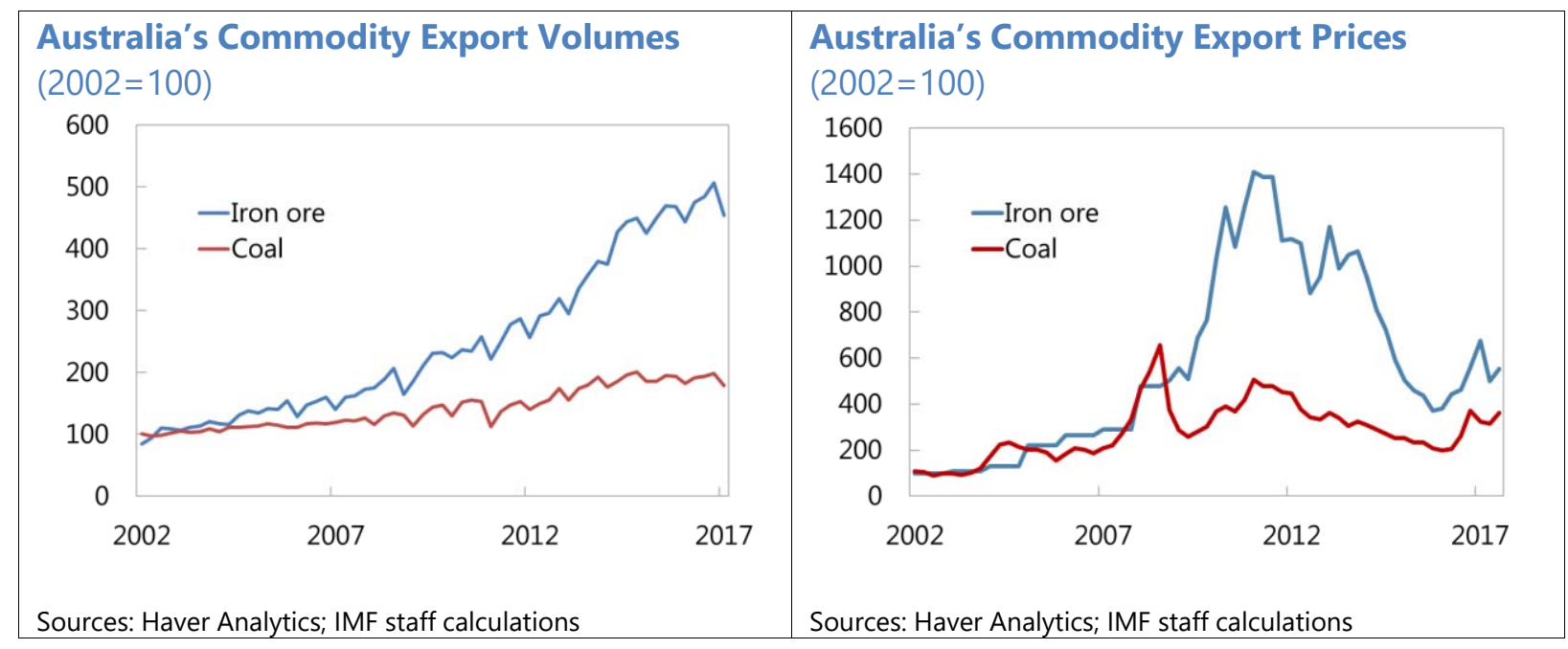




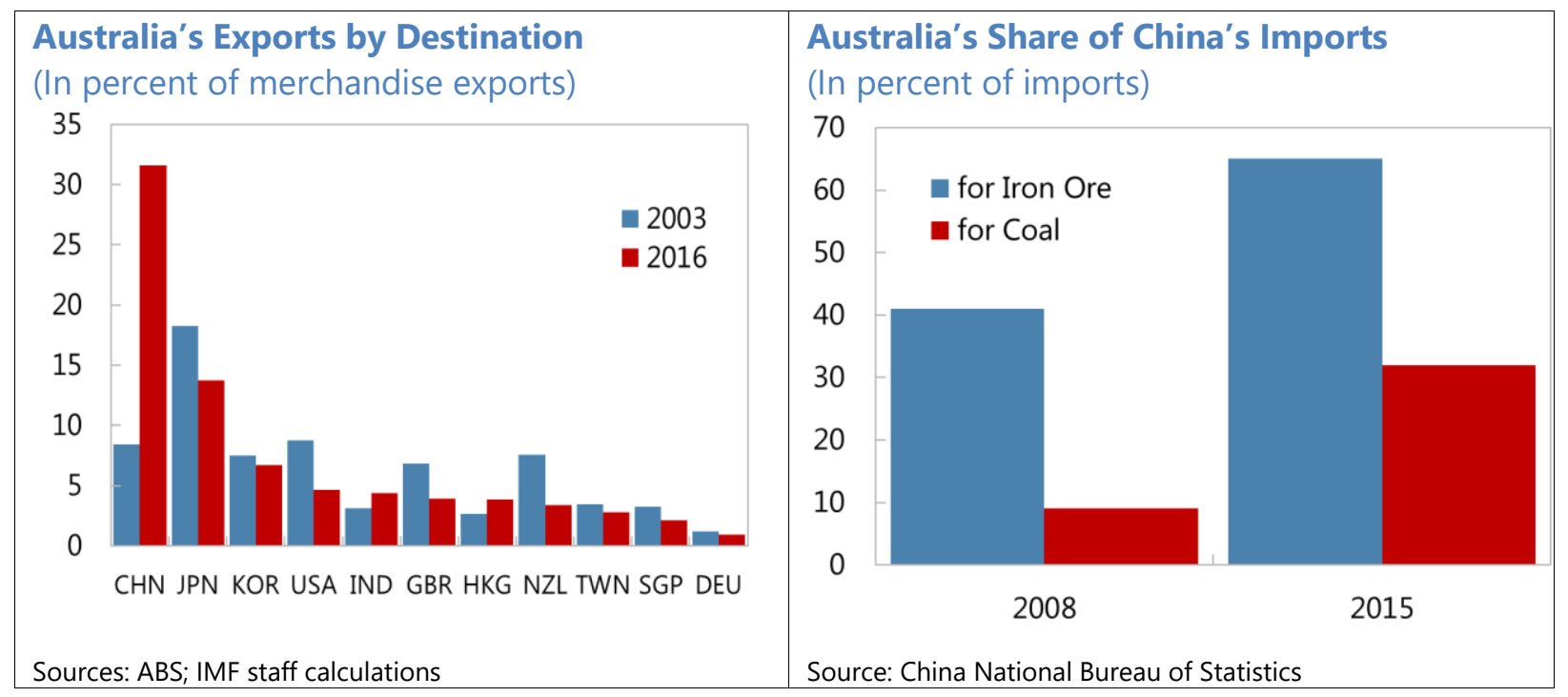

Australia has become a major supplier of China's commodity imports, especially for the steel industry. China's export-led growth in the past has made it the world's largest consumer of commodities, and has spawned key intermediate goods industries, such as steel. China consumes most of its own steel, as it continues to rapidly expand its infrastructure and builds its cities to accommodate its ever-growing consumer base. The steel industry is dependent on imports of iron ore and coking coal, even though China is the world's largest coal producer, at 46 percent of the market. Australia supplies a large share of the remaining demand for coal and iron ore, increasing its share over time in volume terms and even value, despite large fluctuations in global coal and iron ore prices. Because Australia is geographically distant, but has a stable supply chain with China, it has also increased its trading relationships in all goods with other Asian countries along the route to, or close to, China. Roughly 75 percent of all Australian exports now go to Asia, versus 55 percent in 2003.

Three conclusions are deduced from the observed trends in the stylized facts that further motivate the scenario analysis below. First, China has grown strongly as it transforms itself structurally towards a typical advanced economy, led by its services sector. Second, Australia has capitalized on China's strong growth; it has integrated its commodity supplies into China's steel industry, and is increasingly providing more services to China's household sector as well. Third, neither process is concluded, and the linkages between Australia and China are expected to expand in the future, meaning that Australia is also increasingly exposed to the risks China faces during its transition process. The scenario analysis below will attempt to explore in more detail the increased importance of the Australia-China linkages, and provide the policymaker with key results highlighting the likely effects of increasing ties and possible risks on the Australian economy. 


\section{UPSide SCENARIo 1 - Higher ChINESE Household SPENDing ON TOURISM AND EDUCATION}

Takeaway: Understanding the structure of the shock to China is as important as the outcome of the shock in China when interpreting the spillovers to Australia and other countries.

In China, the restructuring process is accelerated in this scenario, which includes permanently higher services demand (Figure 1). There are two components to this process - first, a household preference shift away from saving; second, accelerated restructuring to bring forward productivity growth. The preference shift leads to a relative decline in private saving by 1 percent of GDP, and a lower current account balance, accommodated by an immediate 1.5 percent appreciation of China's real effective exchange rate (REER). Higher productivity lowers factor costs, encouraging firms' labor and capital demand, adding to labor income and financial wealth. Consequently, consumption is 1 percent higher relative to baseline, driven by private saving in the short term, and higher productivity in the longer term.

Higher Chinese consumption continues the trend of higher demand for services, but with no substantive effects on commodities. It is also assumed that the increase in China's household wealth continues the preference shift towards services that often occurs as a country transitions to a high-income economy. Imports of services increase about 7 percent in the medium term and settle at 4 percent in the long term, accounting for about half of the increase in consumption. Commodities play a small role, since the shift in demand is toward less-commodity intensive services, with no notable spillovers to Australia's commodities sector.

However, Australia experiences growth in its services sector (Figure 2). Services exports grow by 2 percent in the first five years, although the long-term supply effect is lower, at 0.9 percent, because of the attenuating REER effect.

Australia experiences distinct short- and long-term effects because of the behavior of its REER. Australia's REER mirrors that of China, depreciating slightly by 0.2 percent followed by a 0.2 percent long-term appreciation. In the short term, all exports increase, about 0.45 percent for final goods, and almost 0.3 percent for intermediate goods. In the long term, Australian final and intermediate exports each decline by about 0.4 percent relative to the baseline scenario, driven by the REER. Similarly, the price of imports cycles in response to the REER so that short-term consumption is 0.2 percent lower, but 0.1 percent higher in the long term. 
Figure 1. Upside Scenario 1 - Results for China

(Deviations from baseline scenario)

1 and 2. Preference shifts lower $\mathrm{CHN}$ private saving and increase education and tourism services 3. While accelerated restructuring strengthens $\mathrm{CHN}$ productivity
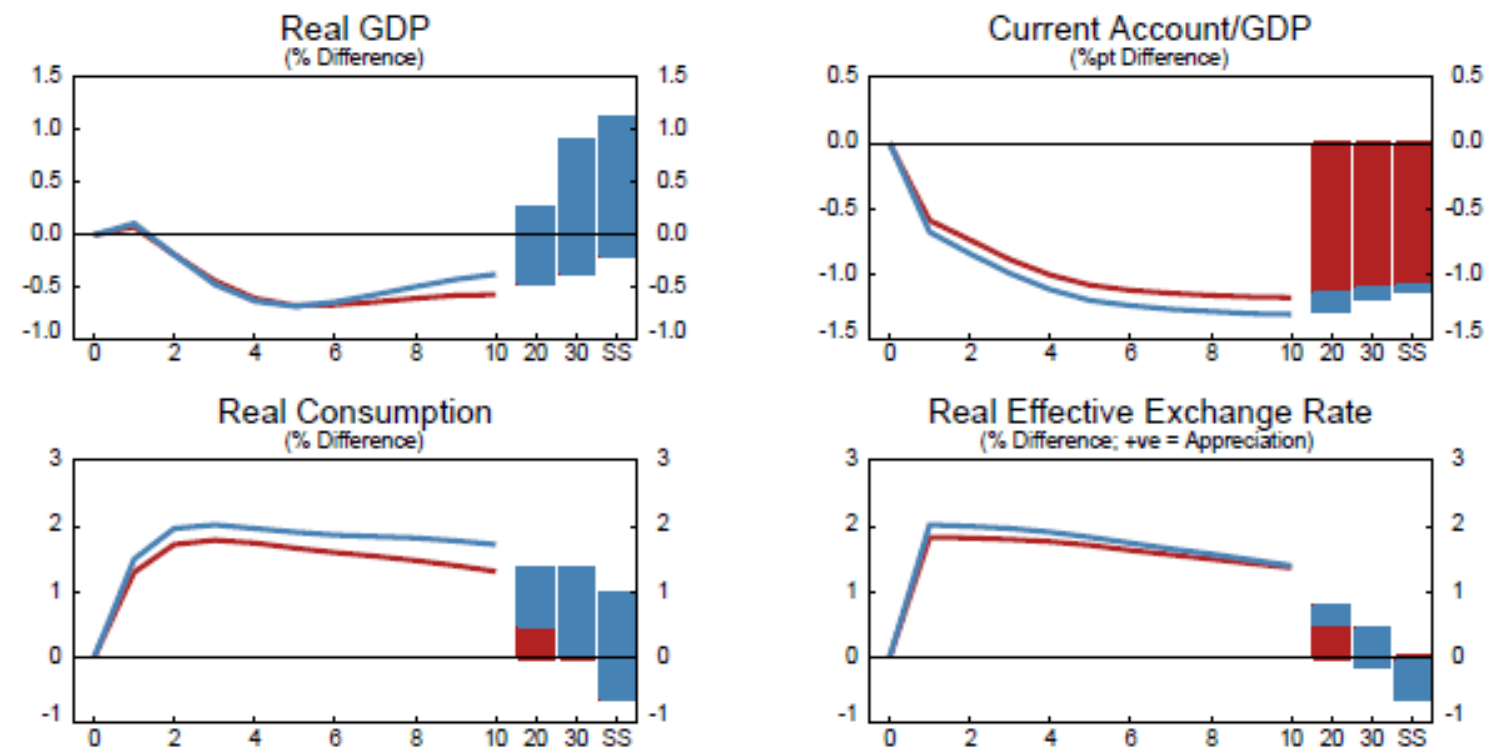

Real Effective Exchange Rate

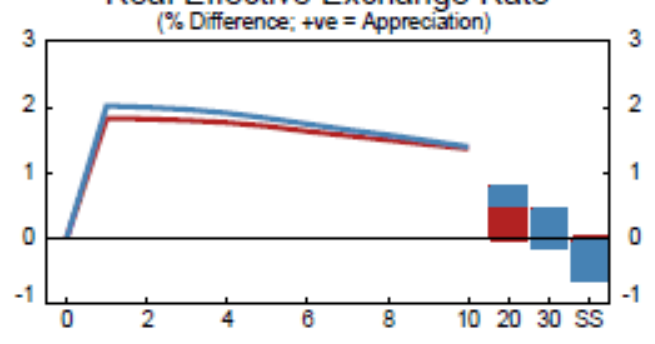

Real Services Imports

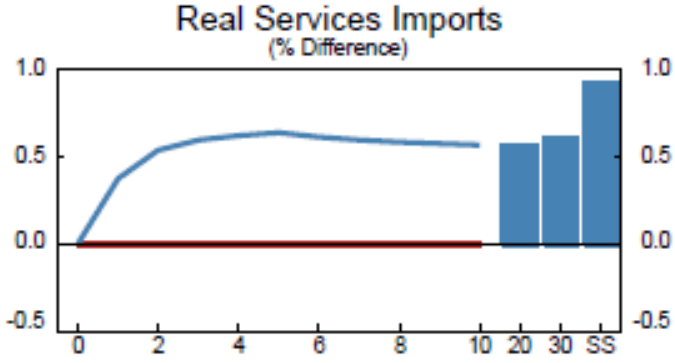

Real Services Demand

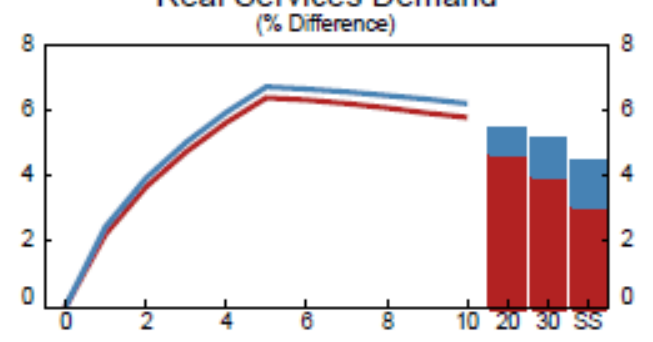

Real Final Goods Imports

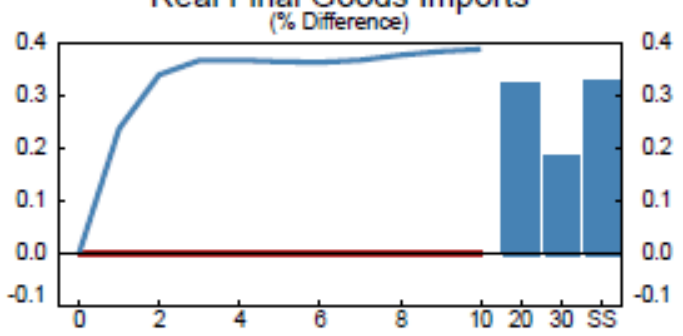

Real Intermediate Imports

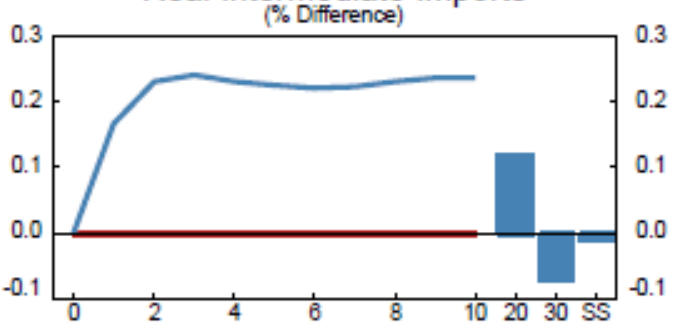

Net Commodities Imports/GDP
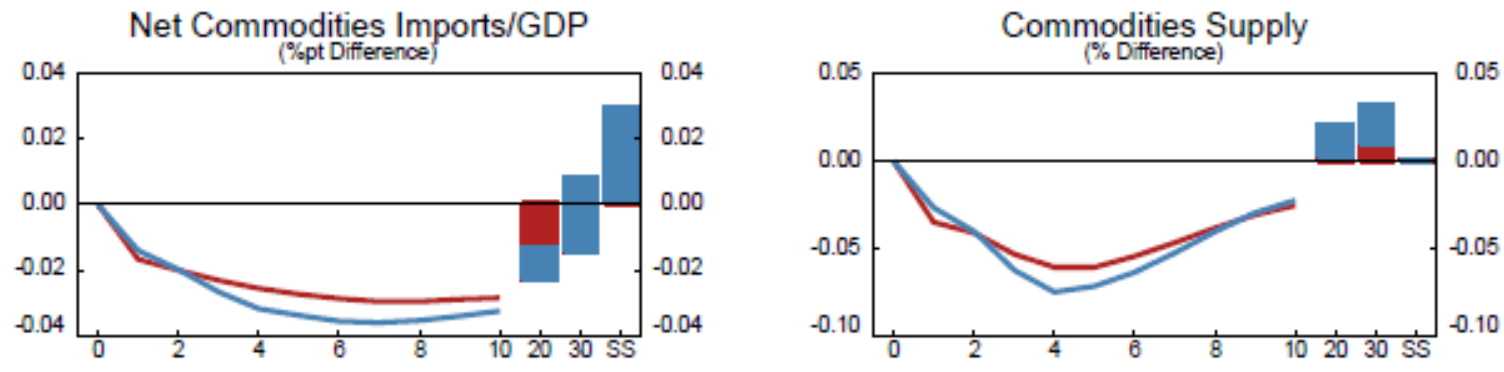

Source: IMF staff calculations 
Figure 2. Upside Scenario 1 - Spillovers to Australia

(Deviations from baseline scenario)

1 and 2. Preference shifts lower $\mathrm{CHN}$ private saving and increase education and tourism services 3. While accelerated restructuring strengthens $\mathrm{CHN}$ productivity
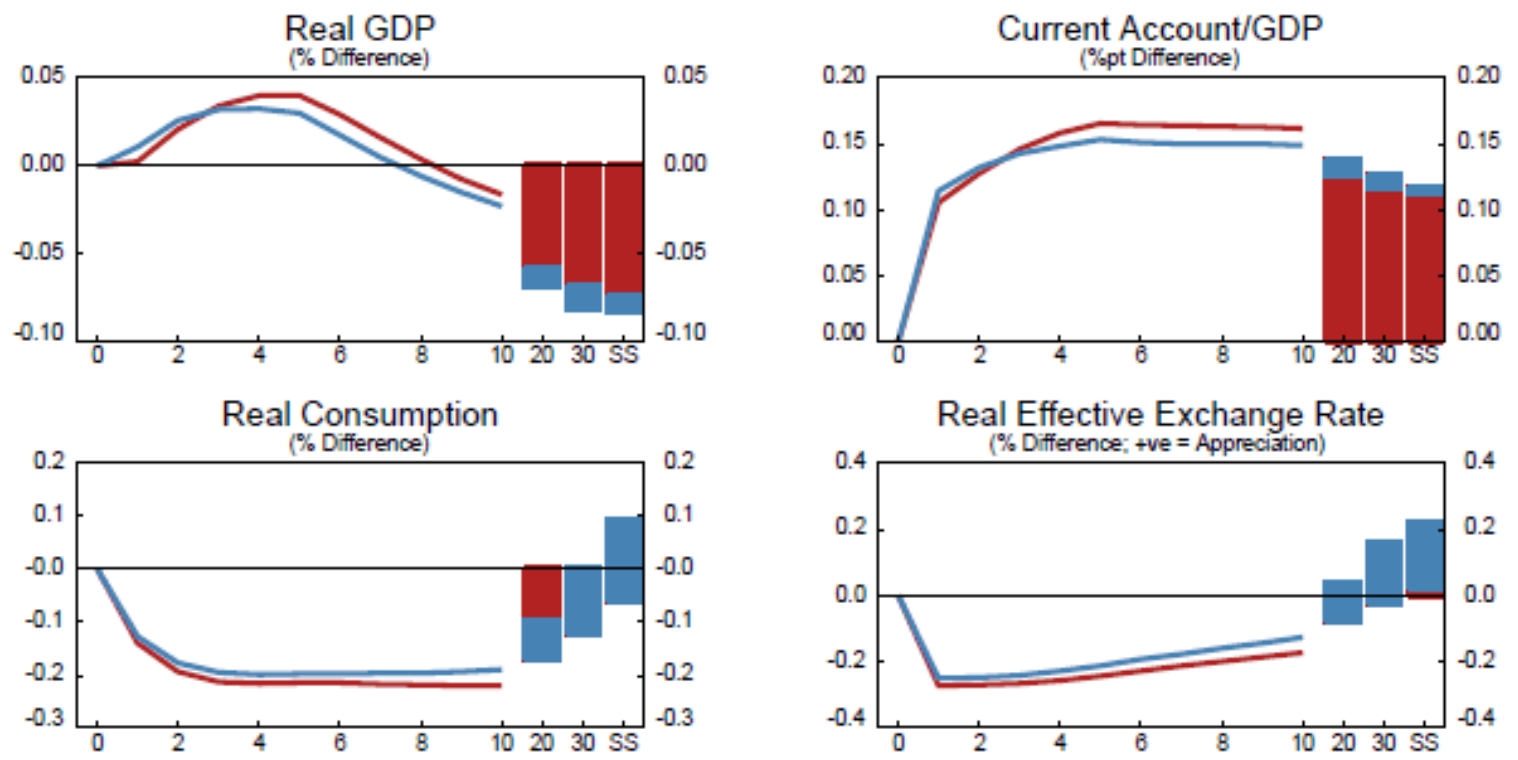

Real Final Goods Exports

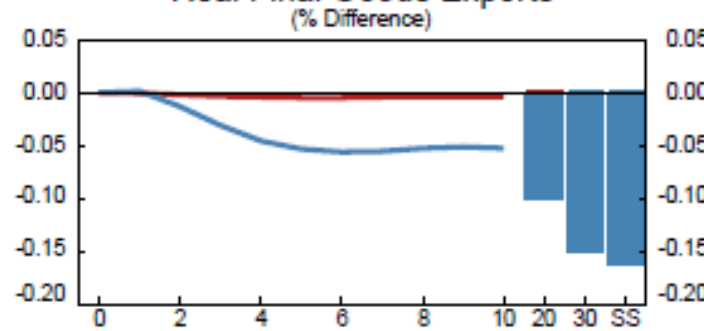

Real Intermediate Exports

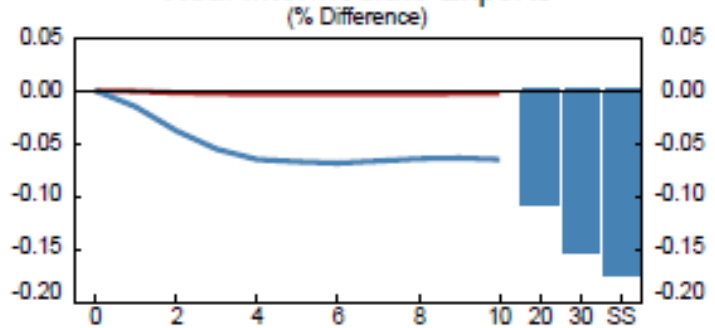

Real Services Exports
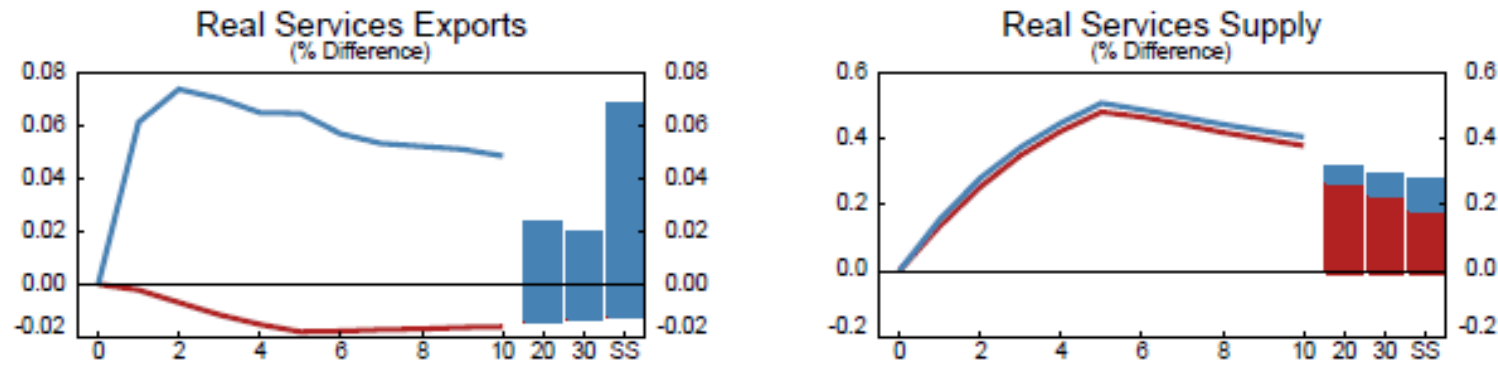

Net Commodities Exports/GDP

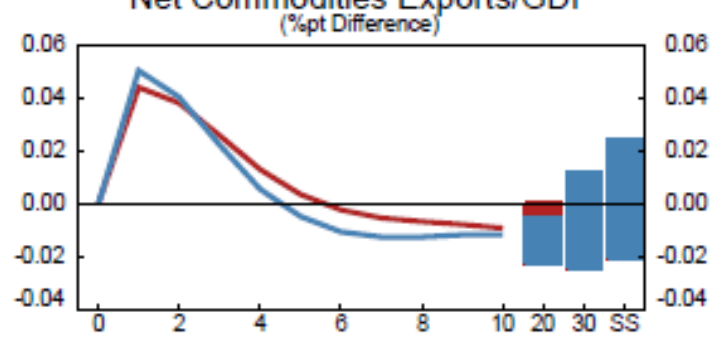

Commodities Supply

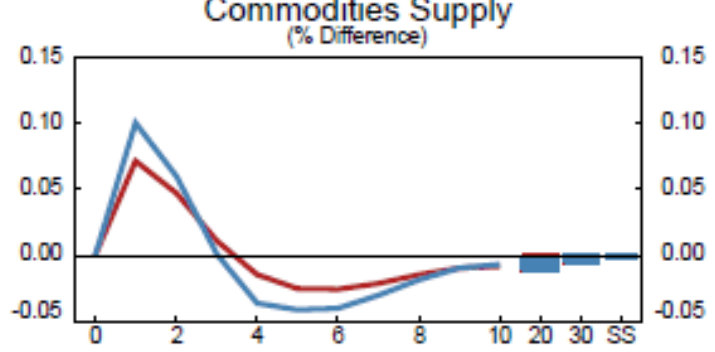

Source: IMF staff calculations 
Overall, the Australian economy experiences a long-lived cycle in its reaction to the shock in China. Australia's real GDP moves from less than 0.1 percent higher in the short term to -0.1 percent in the long term, relative to the baseline. The current account is unambiguously stronger, primarily due to services exports. Yet the real trade volume is more variable than the current account because of the REER and its role in the terms of trade, and is the driver for real GDP. Although a surface reading of the China scenario - lower private saving and higher consumption - seem to indicate a steady, constant development in the economy, it actually conceals two long cycles in productivity and consumption/saving behavior that manifest themselves more fully in China's external sector and time-varying spillovers in Australia.

\section{UPSIDE SCENARIO 2 - IMPROVED OPPORTUNITIES FOR FOREIGN COMMODITIES SUPPLIERS IN CHINA}

Takeaway: Australia is a diversified economy in which its flexible exchange rate regime and its open economy more generally moderate the effects of any given shock.

In this scenario, China further increases the speed at which it addresses overcapacity and inefficiencies in its steel and commodities production (Figure 3). The government restructures and closes more inefficient firms that produce steel than is assumed in the baseline scenario, reducing capacity by an additional 10 percent (about -0.4 percent of GDP, all else being equal). At the same time, the domestic supply of coal and iron ore is reduced by 5 percent because of the government is also accelerating and deepening the restructuring process, but without any fall in domestic demand for those commodities outside of the steel industry. This pushes up the global price of these commodities by 3 percent, permanently, with higher short-term increases.

The process is not painless, as it leads to a mild slowdown in growth; real GDP is permanently 0.6 percent lower relative to baseline. Reducing capacity in these industries lowers demand for other factors of production (labor and capital) which depresses investment, and reduces labor income, so that consumption is about 1 percent lower. The REER depreciates permanently, which encourages exports, allowing some rebalancing between the domestic and external sectors, which is why consumption falls more than real GDP.

China's demand for tourism and education services is lower, in line with consumption. It is about 1.2 percent permanently lower relative to baseline, with a slightly greater reduction in services imports. This is reflected in Australia's services exports being 1.3 percent lower relative to baseline, leading to a commensurate decline in the supply of those services (Figure 4). 
Figure 3. Upside Scenario 2 - Results for China

(Deviations from baseline scenario)

1. Permanent decrease in $\mathrm{CHN}$ commodities production

2. Along with a permanent decrease in $\mathrm{CHN}$ steel production
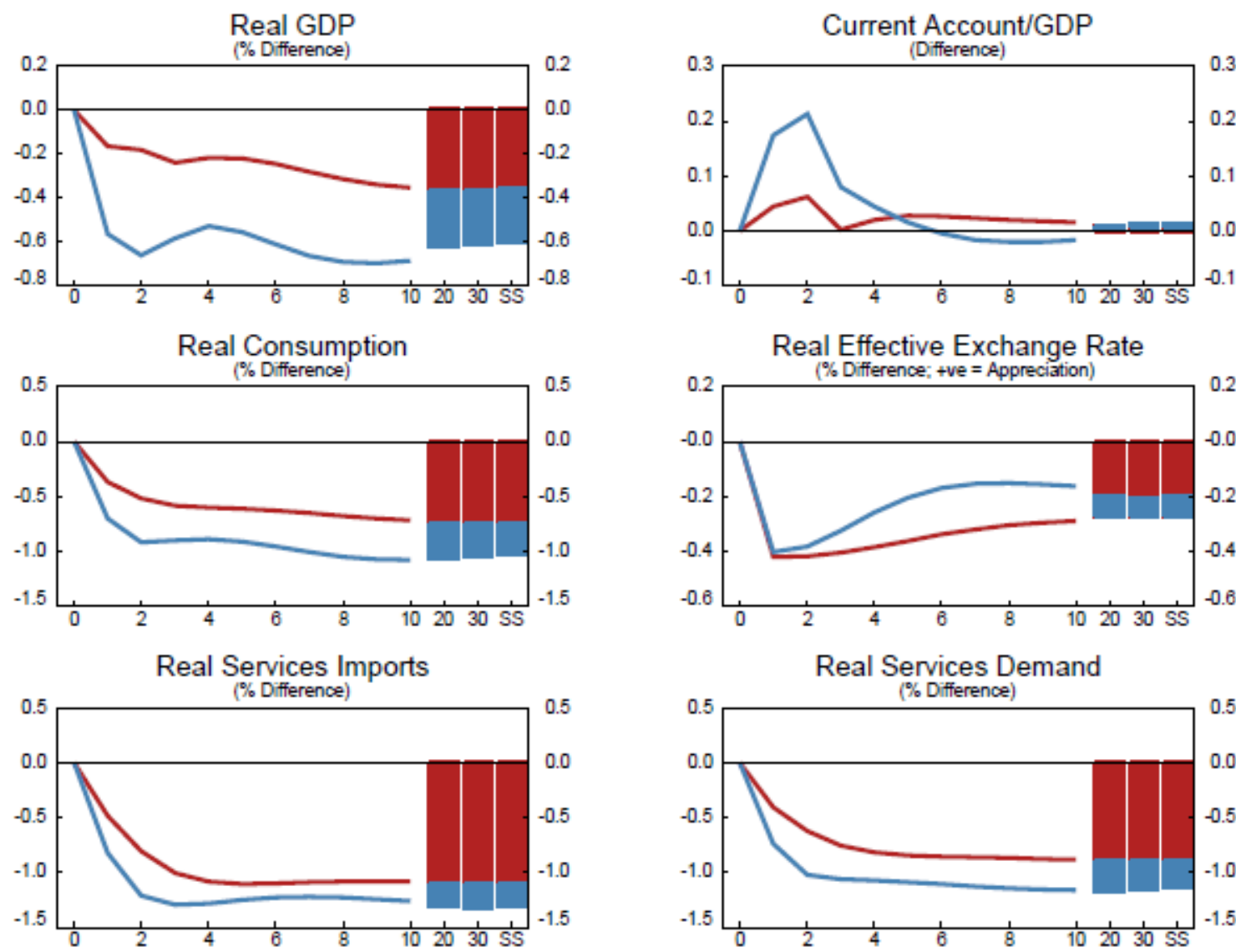

Real Final Goods Imports

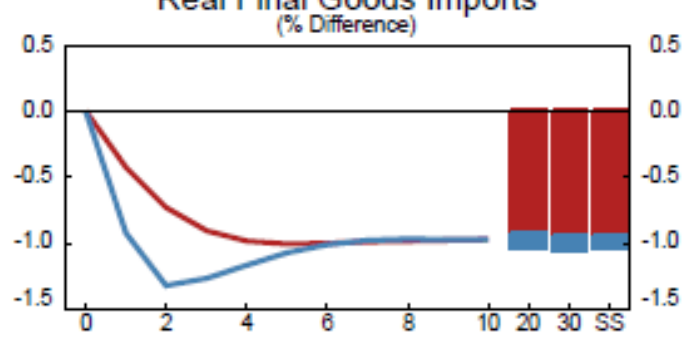

Real Intermediate Imports

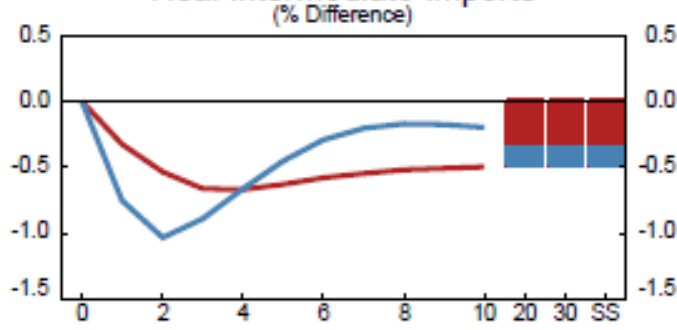

Net Commodities Imports/GDP

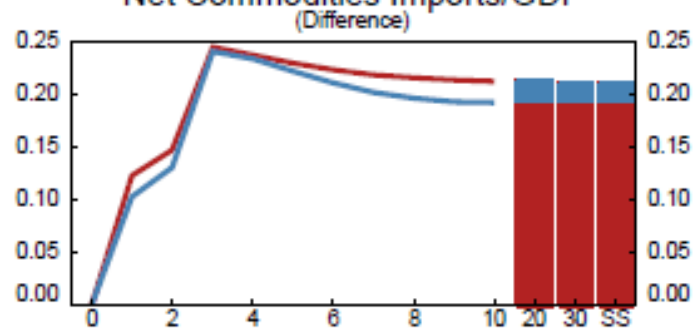

$\underset{(\% \text { Difference) }}{\text { Commodities Supply }}$

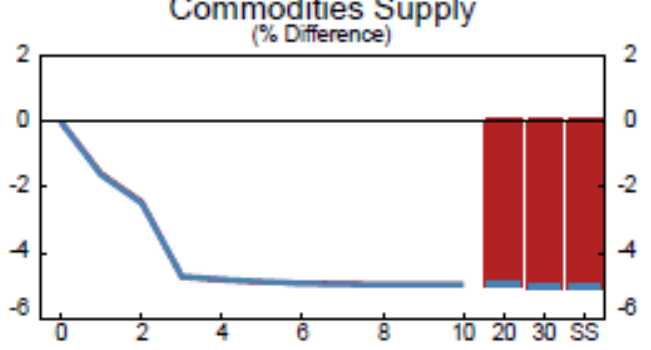

Source: IMF staff calculations 
Overall, the Australian REER appreciates (Figure 4). Because Australia is a commodity exporter, and there is a permanent rise in the global commodity price, the REER appreciates by 0.7 percent on impact, and 0.5 percent in the long term. This has a mixed effect on the Australian economy. On one hand, the appreciation dampens all exports. Net commodity exports rise in value, with an increase in supply. However, the supply increase is short lived, as the higher commodity prices crowd out some foreign demand in Australia's other markets. The increased commodity wealth allows for permanently higher consumption, augmented by a cheaper consumption basket, because of the appreciation.

In sum, real GDP in Australia is slightly lower, but masks a compositional shift induced by its flexible exchange rate, and a diversified economy. The domestic sector is stronger as it benefits from being a commodity exporter. But Australia's external sector is weakened primarily by its decline in services exports (as China's restructuring is not favorable to its household consumption) and from the appreciation and consequent increase in imports relative to baseline.

\section{Downside Scenario - A Disorderly RebalanCing In China ${ }^{5}$}

Takeaway: Although Australia is a diversified economy, it depends on the interaction of its commodities sector with its multiple trading partners, beyond China alone.

China's transition does not go as smoothly as expected. The restructuring of state-owned enterprises (SOES), including the steel industry, is not successful, with a number of firms failing. This manifests itself as a 5-year lower-than-expected path for productivity growth by 1 percent of GDP. This means that real GDP is 5 percent lower in the long term, strictly from the direct productivity effect. Furthermore, the bumpy transition causes a disorderly restructuring of the commodities sector, reducing commodities demand in China by 10 percent permanently. The general economic decline results in lower house prices, reducing housing wealth by 10 percent permanently relative to the baseline scenario, and cutting consumption. The downward effect is exacerbated by a permanent 1 percent increase in the corporate risk premium for SOEs because of the needed reform to harden SOE budget constraints, by assumption. The short-term impact is 2 percent as the general economic situation is worse than expected because of the severity of the other shocks.

In China, real GDP is permanently 10 percent lower ( 4 percent lower on impact) and there is a widespread growth slowdown across the economy (Figure 5). 60 percent of the decline is attributable to the downward revision in productivity. Consumption falls by the same amount, driven by lower labor income for both saving, and liquidity-constrained, households (as the lower productive capacity reduces firms' demands for both labor and capital), and the negative housing wealth shock. China's REER appreciates, as the fall in productivity leads to more expensive goods for export, reducing foreign demand for its goods. This counteracts any shortterm impacts on the REER from capital outflows.

\footnotetext{
${ }^{5}$ While this scenario is illustrative, the productivity shock in this scenario is broadly in line with the range of possibilities explored in the 2017 China Article IV Staff Report (IMF 2017a).
} 
Figure 4. Upside Scenario 2 - Spillovers to Australia

(Deviations from baseline scenario)

1. Permanent decrease in $\mathrm{CHN}$ commodities production

2. Along with a permanent decrease in $\mathrm{CHN}$ steel production
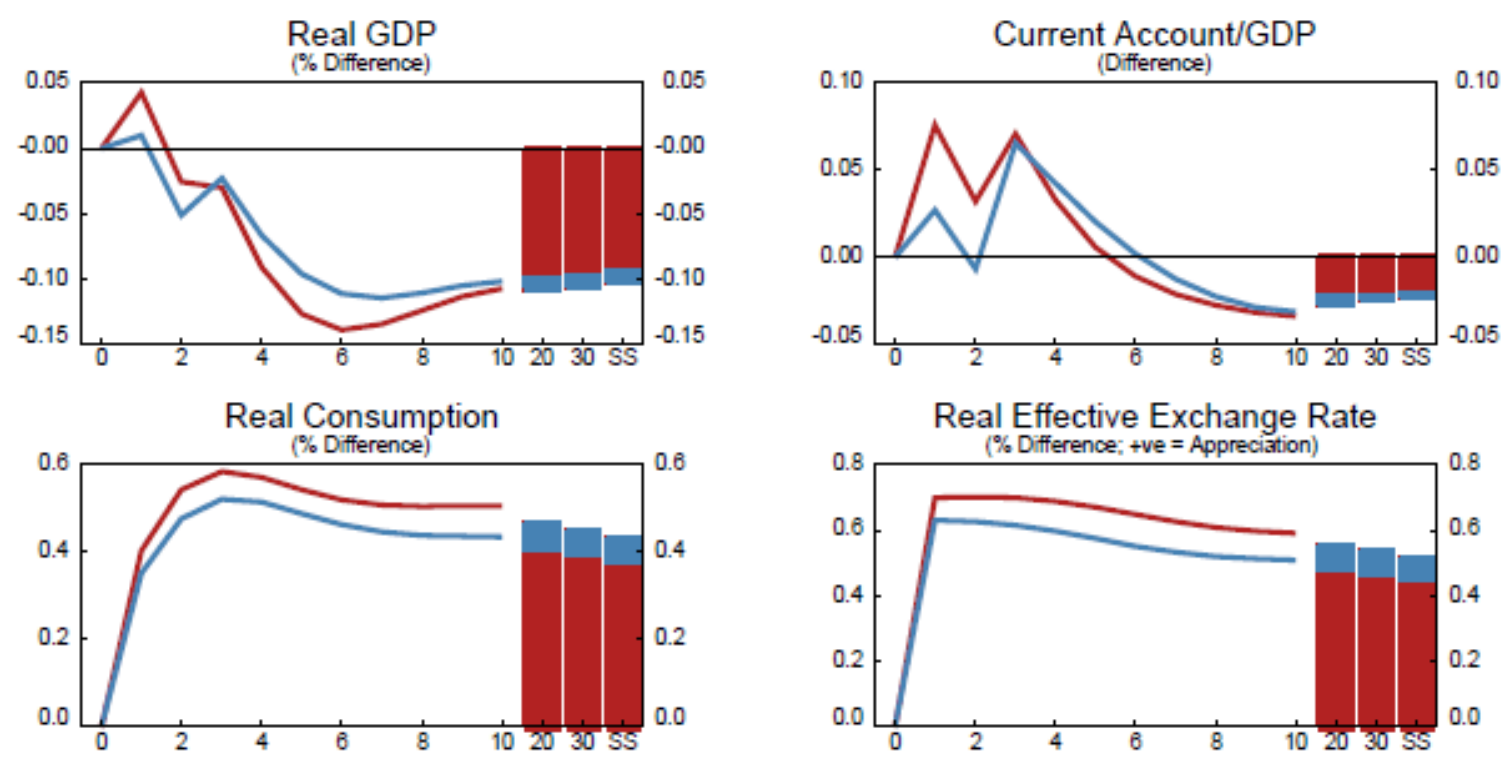

Real Final Goods Exports

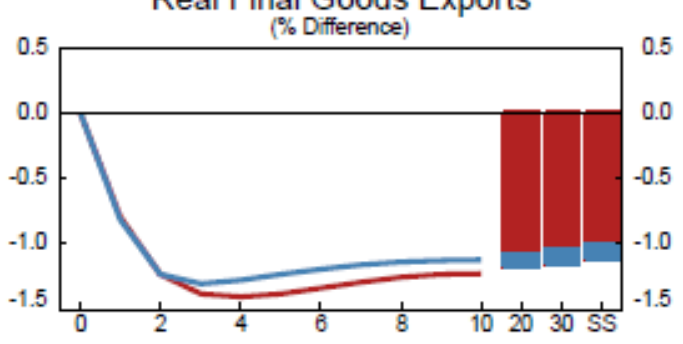

Real Intermediate Exports

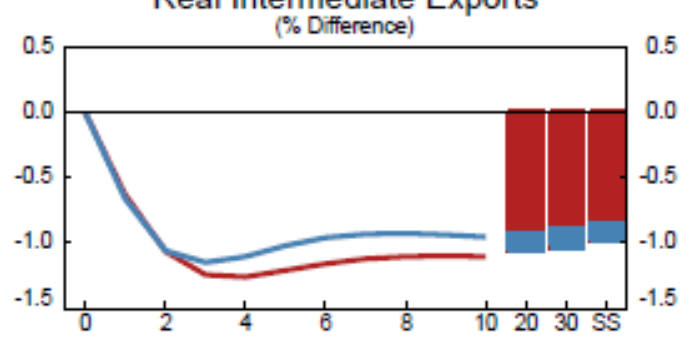

Real Services Exports

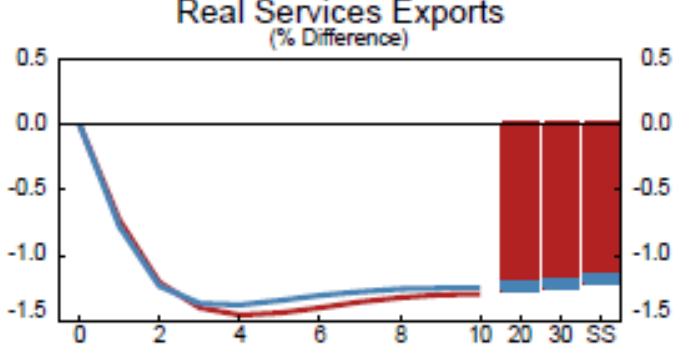

Real Services Supply

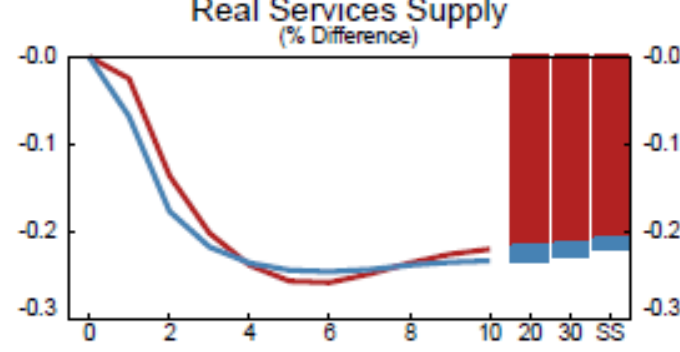

Net Commodities Exports/GDP

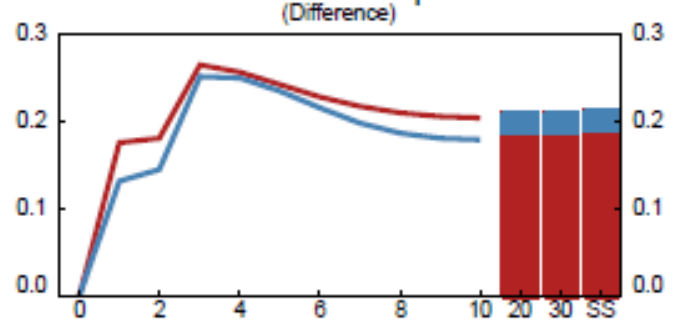

Commodities Supply

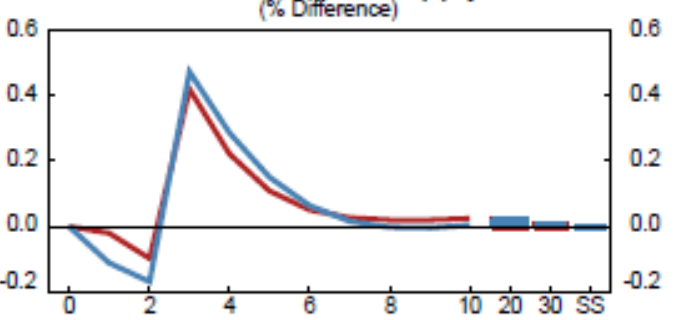

Source: IMF staff calculations 
Figure 5. Downside Scenario - Results for China

(Deviations from baseline scenario)

1 and 2. Restructuring in SOEs (especially steel) with a disorderly impact on commodities 3. Coupled with a decline in $\mathrm{CHN}$ housing prices (and housing wealth)

4. Exacerbated by a permanent increase in the CHN corporate risk premia (SOEs)

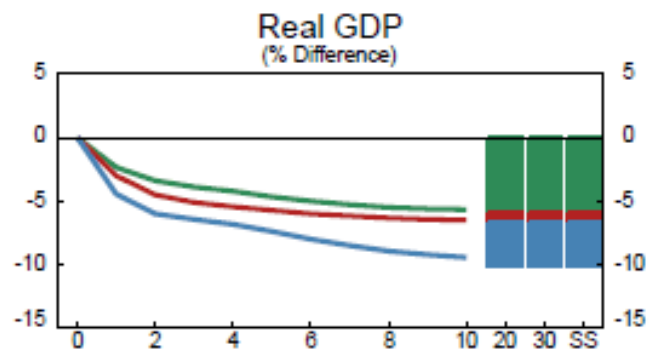

Real Consumption

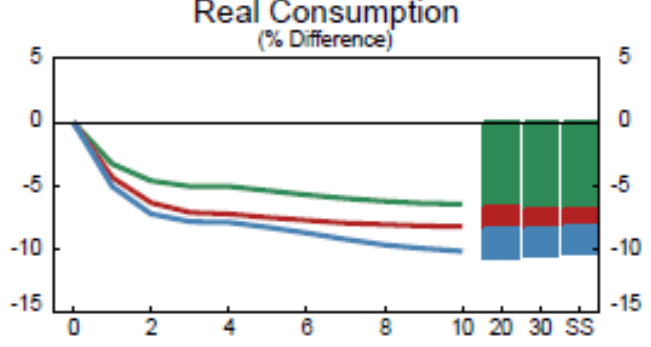

Real Services Imports

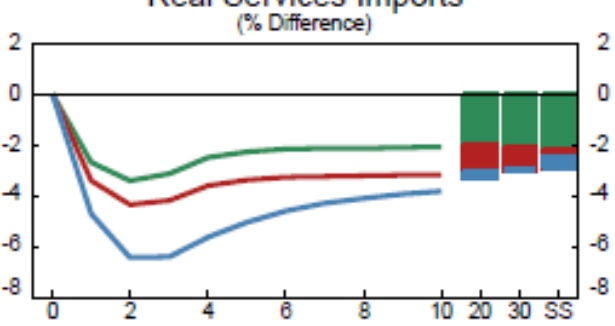

Real Final Goods Imports

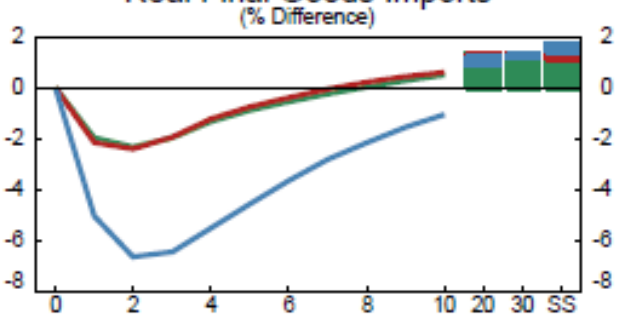

Net Commodities Imports/GDP

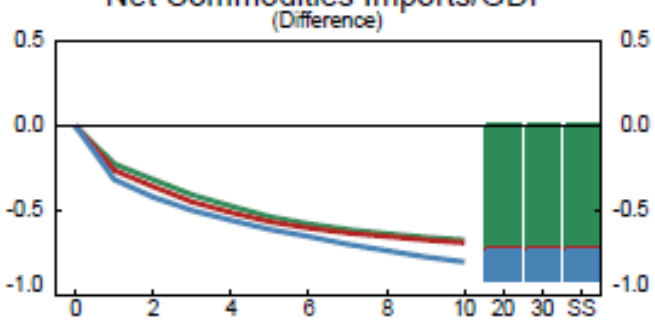

Current Account/GDP

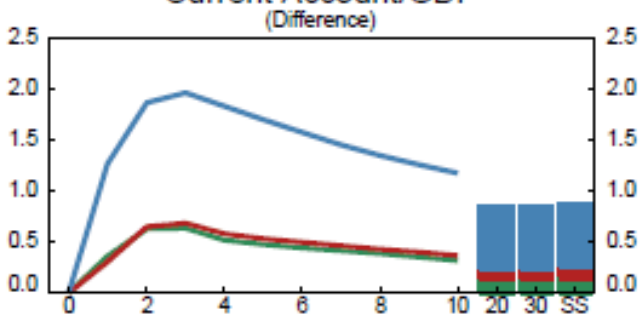

Real Effective Exchange Rate

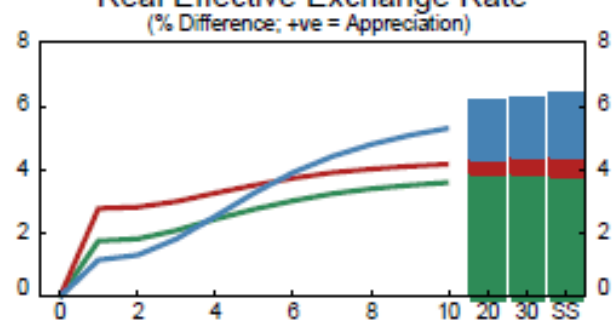

Real Services Demand

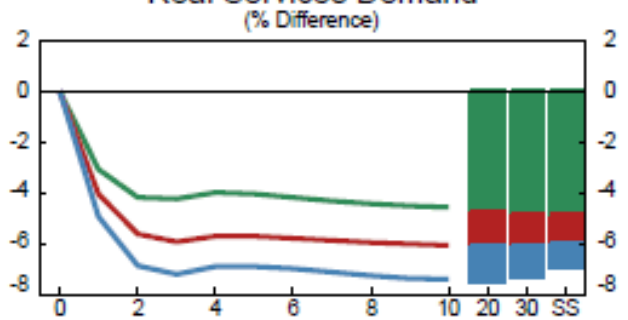

Real Intermediate Imports

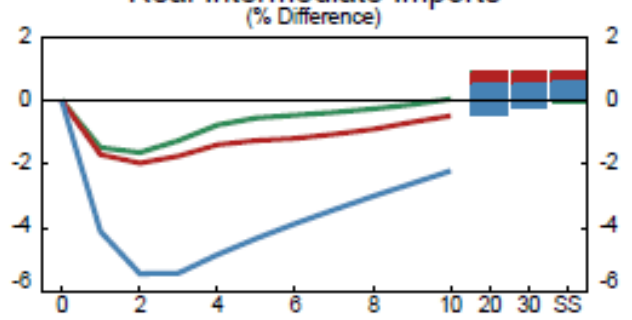

Commodities Supply

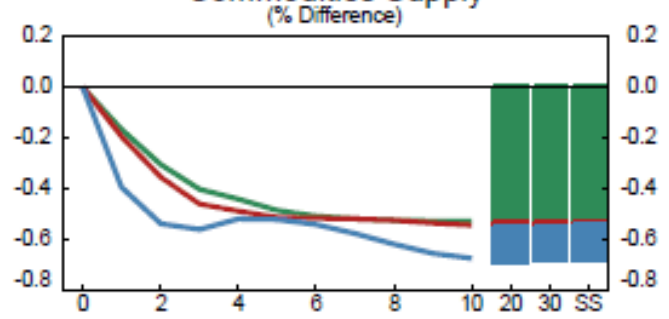


Because consumption declines substantially, there is a direct pass-through to tourism and education services, falling by about 10 percent. Imports of these services decline by 6 percent on impact. However, with the appreciating REER, the negative impact is reduced over time, so that services imports are only 4 percent lower after 10 years relative to baseline, and only 3 percent weaker in the long term beyond 10 years.

Since the failed restructuring is focused in the steel industry, demand for iron ore and coal is hit directly. Net imports of commodities fall as a share of GDP by 1 percent, despite the offsetting effect of the REER appreciation. This accounts for most of the contraction in demand, although the domestic production of coal and iron ore also declines by about 0.5 percent in the short term. The global price of commodities falls around 12 percent permanently (Figure 7, panel 1). In the long term, domestic commodity supply declines by around 0.7 percent.

Australia's outcomes are somewhat mixed, as real GDP falls at first by about 0.4 percent, but then rebounds by an equivalent amount in the long term (Figure 6). In the case of China, real GDP was a sufficient metric for gauging the effects of shocks, but not so for Australia, as the individual sectors exhibit less than straightforward outcomes predicated on Australia's interactions with the rest of Asia. Because of the fall in the global commodities price, and the contraction of Chinese demand, Australian net commodity exports as a share of GDP permanently decline by 1 percentage point in value terms, and its supply declines by 0.7 percent in volume terms. Services exports to China also decline by roughly 3 percent (Figure 7).

Australia's role as a commodity exporter improves its outcomes, as the REER depreciates by 3.5 percent. With weaker global commodity prices, there is a wealth transfer from commodity exporters to importers. Lower wealth in Australia as commodity exporter is exacerbated by the higher cost of imported goods, so consumption is almost 3 percent lower. But the depreciation plays a positive role for Australia as an exporter of a diversified set of goods, and even as a services exporter. Real final goods exports increase by 5 percent, and those of intermediates by over 4 percent in the long term.

The linkages between the roles that Australia plays, as both a major commodity and services exporter, are illustrated in Figure 7. It compares Australia against its three other trading partners of global importance - emerging Asia, advanced Asia, and the United States. In addition, recall from Table 1 that Australia is the largest commodity exporter relative to its GDP, with a net export position of 9 percent of GDP. Therefore, in face of China's downside scenario and the large fall in the global price of commodities it entails (panel 1), Australia sees its commodity exports as a share of domestic GDP decline the most compared to its trading partners (panel 2). This leads to a permanent wealth transfer from commodity exporters (Australia) to importers (also its main trading partners), best measured here by household wealth (panel 3). Australia's loss of wealth (primarily commodities-induced) is only exceeded by China, whose loss is driven by supply shocks to productivity and housing wealth, leading to the appreciation of China's REER. Therefore, Australia depreciates strongly against China, as do Australia's trading partners (panel 4). Taking the cross-exchange rates into consideration, this means that Australia is also depreciating against advanced and emerging Asia and the United States (panel 5). 
Figure 6. Downside Scenario - Spillovers to Australia

(Deviations from baseline scenario)

1 and 2. Restructuring in SOEs (especially steel) with a disorderly impact on commodities 3. Coupled with a decline in $\mathrm{CHN}$ housing prices (and housing wealth)

4. Exacerbated by a permanent increase in the $\mathrm{CHN}$ corporate risk premia (SOEs)

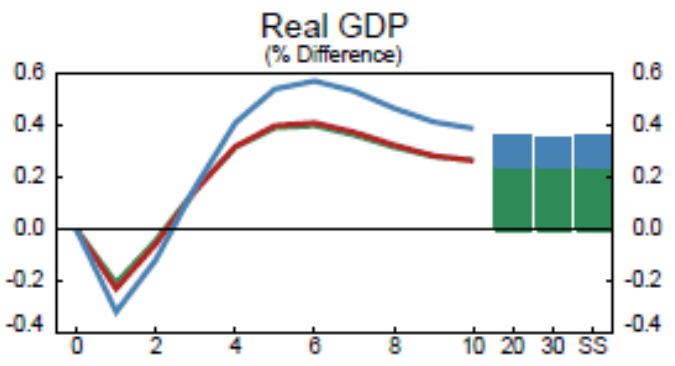

Real Consumption

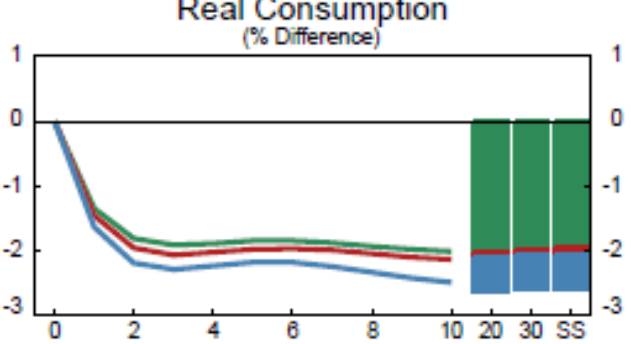

Real Final Goods Exports

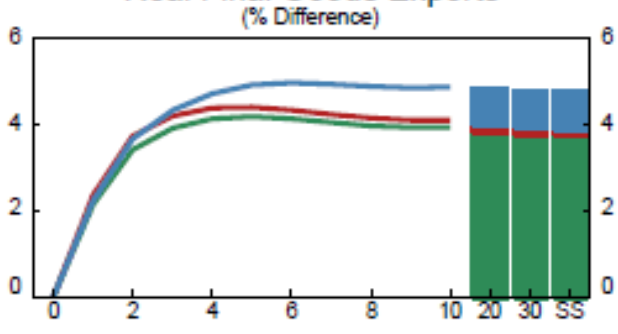

Real Services Exports

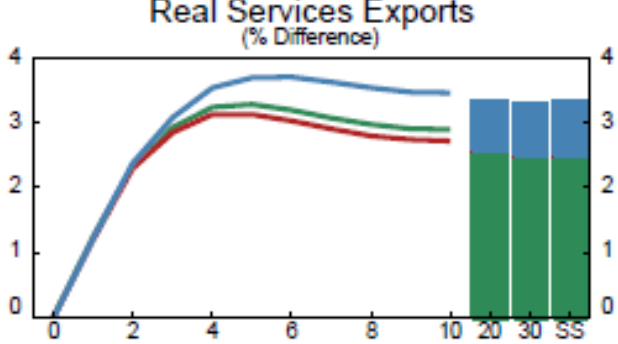

Net Commodities Exports/GDP

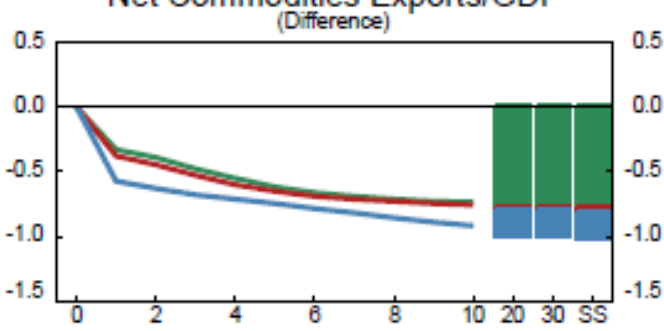

Current Account/GDP

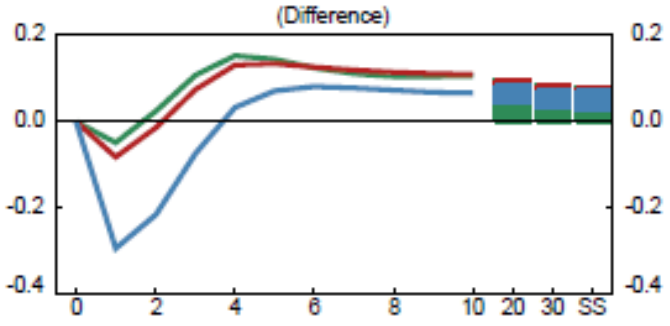

Real Effective Exchange Rate

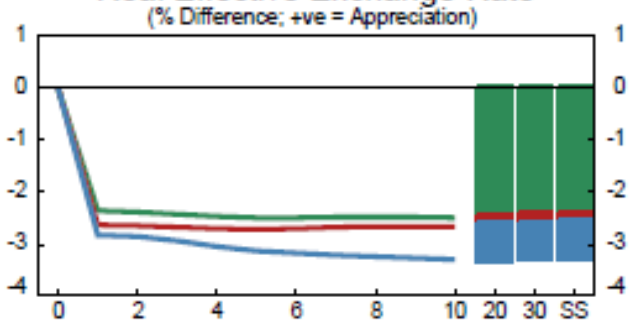

Real Intermediate Exports

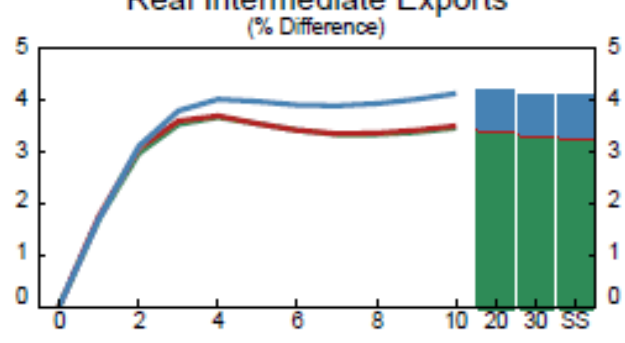

Real Services Supply

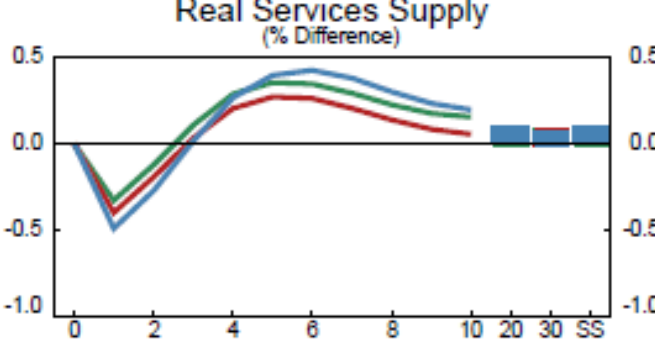

Commodities Supply

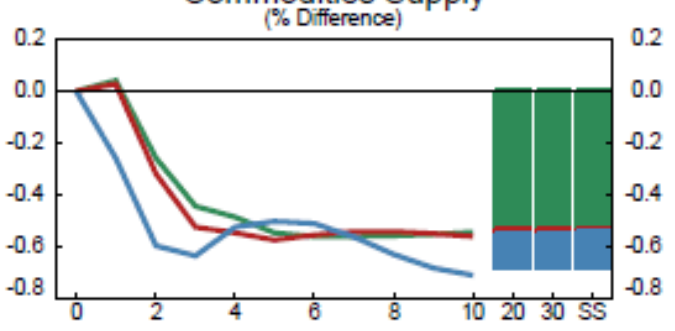


Figure 7. Downside Scenario - Interaction of the Commodities and Services Sectors (Deviations from baseline scenario)

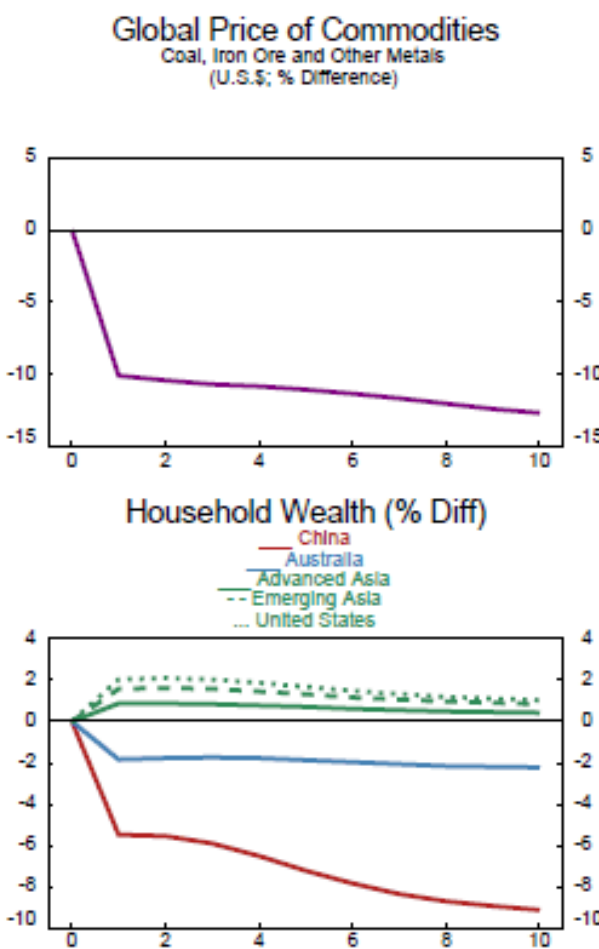

Australia's Real FX Rates (\% Diff; AUD/lc)

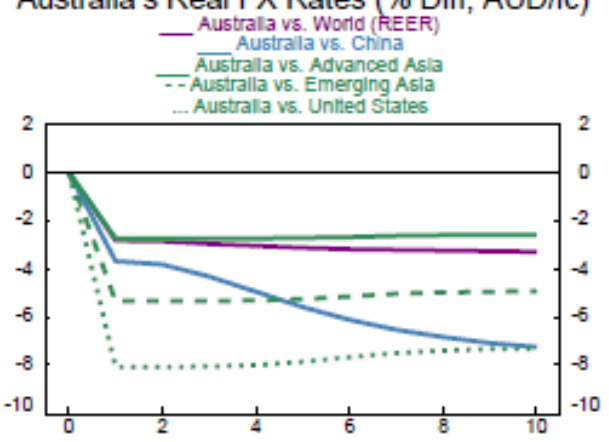

Net Commodity Exports (\%GDP Diff)
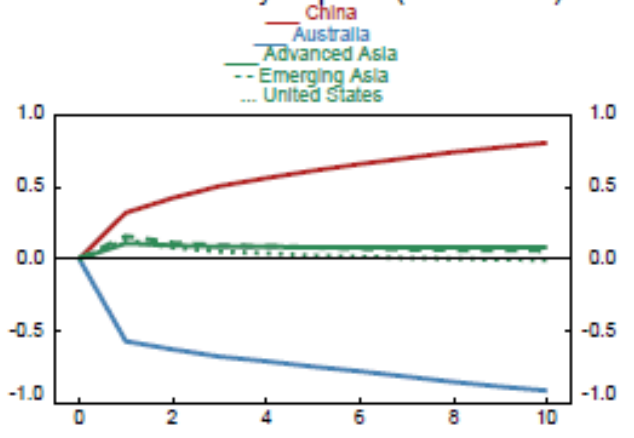

China's Real FX Rates (\% Diff; Ic/RMB)

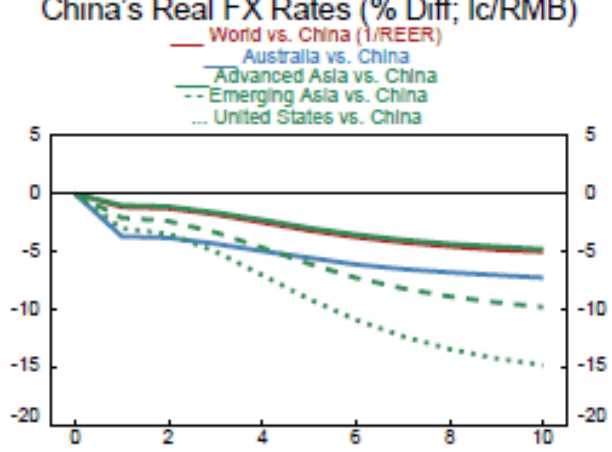

Australia's Exports of Consumption Services (\% Diff)

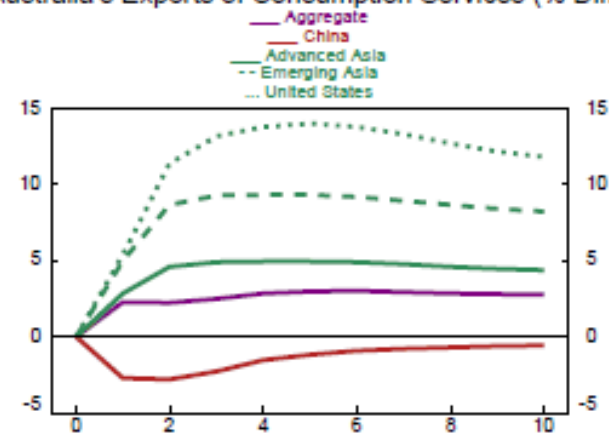

Source: IMF staff calculations

Consequently, Australia's services exports benefit - although its service exports to China decline because of the shock in China, its depreciation against its other trading partners makes its services cheaper abroad (panel 6).

For Australia's trading partners, especially in the rest of Asia, there are two competing effects which allow for Australia to benefit on net. The first (negative, and weaker) effect is China's lower demand for goods. The second (positive, but stronger) effect is the large decline in global commodities prices because of China, which encourages demand for commodities and stimulates GDP in most of the rest Asia as net commodity importers. Other net commodity importers also benefit, with positive spillovers to the rest of Asia. 
The outcomes of this scenario are conditional on the assumption that there is no financial contagion from China, and an unconstrained adjustment in China's REER. A scenario with substantial financial turmoil would dampen an otherwise optimistic outcome for Australia. This said, this scenario outlines qualitatively the intricate real channels through which Australia is affected by the shocks and the foundations for the flexible adjustment.

\section{Conclusions}

Australia and China have strong linkages that are growing over time as China carries on with its economic transition. Trade in commodities and services are constantly growing. Australia has established itself as a dominant player in some key Chinese import markets, particularly for steel. Chinese households also turn to Australia as they increasingly consume abroad (not just domestically) reflected in both increasing value and volume terms. Outcomes in both countries are heavily dependent on China's continuing transition to a consumer-led, services-driven economy. At the same time, Australia continues to broaden its own services base, and complete its expansion of commodities production that began with the commodity price boom.

Scenario analysis based on modifications to China's economic transition was conducted, with the following key takeaways:

- First, the simplest, and most pervasive, takeaway is that while real GDP in Australia experiences only small changes in response to shocks in China, these movements mask much broader movements in the composition of GDP, whether it be between domestic and external demand, or between sectors in the economy.

- Second, a more encompassing analysis of the effects on Australia from these China scenarios, requires a closer understanding the structure of the shocks that are occurring and their ramifications in all sectors within China (as in the case of consumption/saving rebalancing); focusing on the observable outcomes strictly in the sectors that are the source of spillovers to Australia, such as tourism and education flows, or movements in commodities or other trade flows, will render the analysis incomplete.

- Third, once the shock is understood in the context of China, spillovers to Australia should be placed in the context of its relatively diversified economy, and its willingness to accept the moderating influence of its flexible exchange rate and open economy (especially when considering shocks to China's commodities sector).

- Finally, Australia's diversified economy is also reliant on strongly established trading relationships with the rest of Asia, both advanced and emerging countries, not just China alone, which mitigate the effects from widespread shocks to China, as is the case with the downside scenario.

The stylized facts also demonstrate that the rest of Asia is increasingly important for Australia. The charts for tourism, education and the destination of exports illustrate that both advanced and emerging Asia already have a growing impact. Table 1 shows that trade linkages of the rest of Asia with Australia are similar in size to those between Australia and China. China may be Australia's largest trading partner, but the rest of Asia is also rapidly growing, and is a potential market for Australia's future expansion. 


\section{REFERENCES}

Anderson, D., B. Hunt, M. Kortelainen, M. Kumhof, D. Laxton, D. Muir, S. Mursula, and S. Snudden, 2013, "Getting to Know GIMF: The Simulation Properties of the Global Integrated Monetary and Fiscal Model,” International Monetary Fund, IMF Working Paper 13/55.

Bernanke, B., M. Gertler and S. Gilchrist, 1999, "The Financial Accelerator in a Quantitative Business Cycle Framework," in J. Taylor and M. Woodford, eds., Handbook of Macroeconomics, Volume 1c, Amsterdam: Elsevier.

Blanchard, O., 1985, “Debts, Deficits and Finite Horizons," Journal of Political Economy, 93, 223-47.

Department of Foreign Affairs and Trade, 2015, Trade in Services, Australia, 2014. Canberra: Department of Foreign Affairs and Trade. ,2017, Trade in Services, Australia, 2016. Canberra: Department of Foreign Affairs and Trade.

Dizioli, A., B. Hunt and W. Maliszewski, 2016, "Spillovers from the Maturing of China's Economy”, International Monetary Fund, IMF Working Paper 16/212.

East Asian Bureau of Economic Research and China Center for International Economic Exchanges, 2016, Partnership for Change: Australia-China Joint Economic Report, 2016. Canberra: ANU Press.

International Energy Administration, 2017, Coal Information 2017.

International Monetary Fund, 2017a, People's Republic of China: 2017 Article IV

Consultation - Staff Report, International Monetary Fund, IMF Country Report No. $17 / 247$.

,2017b, World Economic Outlook, April 2017 - Gaining Momentum? Washington D.C.: International Monetary Fund.

International Trade Administration, 2017, Global Steel Trade Monitor - Steel Exports Report: China, March 2016. Washington D.C.: International Trade Administration, Steel Import Monitoring and Analysis.

Kumhof, M., D. Laxton, D. Muir, and S. Mursula, 2010, "The Global Integrated Monetary and Fiscal Model (GIMF) - Theoretical Structure” International Monetary Fund, IMF Working Paper 10/34.

Tourism Research Australia, 2017, International Visitor Survey Results, Canberra: Austrade.

Weil, P., 1987, "Permanent Budget Deficits and Inflation," Journal of Monetary Economics, 20, 393-410.

Yaari, M., 1965, “Uncertain Lifetime, Life Insurance, and the Theory of the Consumer," Review of Economic Studies, 32, 137-50. 


\section{Appendix I: Key Assumptions Underlying the Simulations}

\section{Key Model Assumptions for ANZIMF}

1. All agents in the model (including households, firms and the fiscal and monetary authorities) have perfect foresight.

2. The model has non-linearities in the financial accelerator, and potential for non-linearities in the conduct of monetary policy by either encountering the zero-interest-rate floor or using monetary accommodation (features not used here). Otherwise, the model is approximately linear for small enough shocks.

3. All countries in ANZIMF have the same economic structures, differing only through their parameterization and calibration.

4. The baseline calibration of ANZIMF is based on parameter values consistent with 2015 for the great ratios to GDP such the capital stock, government debt and deficit, net foreign assets and current account balance, and national accounts aggregates as well as trade flows, and 2015 and 2016 for services data.

5. The real exchange rate is a "jumper," adjusting immediately in the first year to shocks, since it follows the standard forward-looking, risk-adjusted uncovered interest rate parity condition which equates the forward sum of Australia-international interest rate differentials with the one-year in the exchange rate. However, there is no financial friction in the equation required to bring the net foreign asset position to its steady state, as the net foreign asset position and its dynamics solve endogenously as part of the OLG framework.

6. China has a flexible exchange rate, with no capital controls. Capital controls are hard to model in this context, and in the current environment, it is not clear that China would always impose them if there were to be sudden movements in elements of the balance of payments.

7. There are no substantial financial market channels. ANZIMF only has a financial accelerator (albeit using the full general equilibrium form with non-linearities), and assumes complete domestic ownership of firms. All net foreign asset positions are denominated in U.S. dollars, in all countries. Some financial channels could be mimicked by correlated, exogenouslyspecified shocks.

8. The model is at an annual frequency, so degree of detail for some of the economy's dynamics are lost, particularly in the first year for investment.

\section{Scenario Assumptions}

The three scenarios result from shocks originating in China. Australia and the rest of the world interact with spillovers that are either direct, via third countries, or via the global commodities market for coal, iron ore, and other metals. 


\section{Upside Scenario 1}

This scenario is composed of three separate shocks, where the first two shocks are presented in combination:

1. Lower private saving. Shift in the preference for private saving for a permanent reduction of 1 percent of baseline GDP, phased in over nine years. This is a permanent reduction in the rate of time preference.

2. Higher consumption of services. Increase in the household bias to consumption of services over goods over 5 years such that the increase in consumption of imported tourism and education services will be roughly half of the entire increase in aggregate consumption.

3. Higher productivity. Permanent increase in productivity in the tradable and nontradables sectors such that, in the presence of the reduction in private saving, there is a permanent 1 percent increase in real consumption. It is phased in over 25 years, starting in the sixth year.

\section{Upside Scenario 2}

The scenario is composed of two separate shocks:

1. Lower commodity supply. Permanent 5 percent reduction in the domestic supply of commodities. Phased in evenly over 3 years.

2. Decrease in steel supply. The goal is a permanent 10 percent reduction in steel production, translating roughly into -0.4 percent of GDP. Permanent reduction in investment for tradables firms such that their production is lower by 0.4 percent of GDP, including the endogenous decline that occurred by lowering the commodity supply. Phased in over 3 years.

\section{Downside Scenario}

The scenario is composed of four separate shocks, where the first two shocks are presented in combination:

1. Lower productivity. Permanent 5 percent reduction in tradables and nontradables productivity. Phased in as a -2 percentage points on productivity growth in year 1 , and -1 percentage point on growth in years 2 through 4 .

2. Lower commodities demand. Permanent 10 percent reduction in demand for commodities. Phased in, with -4 percentage points in year 1, and -2 percentage points in years 2 through 4 .

3. Lower housing wealth. 10 percent decline on impact in year 1 in nontradable sector net worth, to proxy for the permanent fall in the value of the housing stock.

4. Increased corporate risk premia. Permanent 1 percentage point increase in the corporate risk premia for both tradable- and nontradable-producing firms after a 2-percentage point increase on impact in year 1. 